\title{
Current status of global Ganoderma cultivation, products, industry and market
}

\section{Hapuarachchi KK 1,2,3, Elkhateeb WA ${ }^{4}$, Karunarathna $\mathrm{SC}^{5}$, Cheng $\mathrm{CR}^{6}$, Bandara $\mathrm{AR}^{2,3,5}$, Kakumyan $\mathrm{P}^{3}$, Hyde $\mathrm{KD}^{2,3,5}$, Daba $\mathrm{GM}^{4}$ and Wen $\mathrm{TC}^{1^{*}}$}

\author{
${ }^{1}$ The Engineering Research Center of Southwest Bio-Pharmaceutical Resources, Ministry of Education, Guizhou \\ University, Guiyang 550025, Guizhou Province, China \\ ${ }^{2}$ Center of Excellence in Fungal Research, Mae Fah Luang University, Chiang Rai 57100, Thailand \\ ${ }^{3}$ School of Science, Mae Fah Luang University, Chiang Rai 57100, Thailand \\ ${ }^{4}$ Department of Chemistry of Microbial Natural Products, National Research Center, Tahrir Street, 12311, Dokki, \\ Giza, Egypt. \\ ${ }^{5}$ Key Laboratory for Plant Diversity and Biogeography of East Asia, Kunming Institute of Botany, Chinese Academy of \\ Sciences, 132 Lanhei Road, Kunming 650201, China \\ ${ }^{6}$ School of Chemical Engineering, Institute of Pharmaceutical Engineering Technology and Application, Sichuan \\ University of Science \& Engineering, Zigong 643000, Sichuan Province, China
}

Hapuarachchi KK, Elkhateeb WA, Karunarathna SC, Cheng CR, Bandara AR, Kakumyan P, Hyde KD, Daba GM, Wen TC 2018 - Current status of global Ganoderma cultivation, products, industry and market. Mycosphere 9(5), 1025-1052, Doi 10.5943/mycosphere/9/5/6

\begin{abstract}
Among many traditional medicines, Ganoderma has been used in Asian countries for over two millennia as a traditional medicine for maintaining vivacity and longevity. Research on various metabolic activities of Ganoderma have been performed both in vitro and in vivo studies. However, it is debatable whether Ganoderma is a food supplement for health maintenance or a therapeutic "drug" for medical purposes. Over the past two decades, the Ganoderma industry has developed greatly and today offers thousands of products to the markets. Despite the large market, there are problems with the industry which prevent it from establishing an effective market. This paper describes the current status of the world Ganoderma cultivation, products, industry and provides suggestions for facilitating further research.
\end{abstract}

Key words - lingzhi - secondary metabolites - traditional medicine

\section{Introduction}

Ganodermataceae is a large family of polypores with seven accepted genera: Amauroderma, Foraminispora, Furtadoa, Ganoderma, Haddowia, Humphreya and Polyporopsis (Richter et al. 2015, Costa-Rezende et al. 2017) and 592 epithets, of which most species are classified in the genus Ganoderma (www.indexfungorum.org, accessed 18 September 2018). Members of Ganodermataceae are cosmopolitan basidiomycetes (Cao \& Yuan 2013) and are distinct from other families of polypores in having a peculiar type of double-walled basidiospores (Adaskaveg \& Gilbertson 1988). The genus Ganoderma was established by Karsten (1881) with Ganoderma lucidum (Curtis) P. Karst. as the type species (Moncalvo \& Ryvarden 1997). Ganoderma species are distributed worldwide (Pilotti 2005) and the fruiting bodies of Ganoderma grow from living, or more commonly, from dead trunks or branches of trees. They grow as facultative parasites that can 
live as saprobes on decaying wood (Turner 1981). Two types of fruiting bodies are produced, depending on the species: a laccate fruiting body with a shiny upper surface, or a non-laccate fruiting body with a dull upper surface (Smith \& Sivasithamparam 2000, Pilotti et al. 2004). Ganoderma species are not classified as edible mushrooms, since they have a bitter taste and hardness in their fruiting bodies and do not have the fleshy texture characteristic of true edible mushrooms (Jong \& Birmingham 1992). The double walled basidiospores with interwall pillars are a key diagnostic feature for the genus (Smith \& Sivasithamparam 2000, Li et al. 2013). Ganoderma species have important economic value, due to their medicinal properties and pathogenicity (Dai et al. 2007, 2009). Ganoderma species cause white rot of hard woods by decomposing lignin, cellulose and related polysaccharides (Hepting 1971, Adaskaveg et al. 1991). Ganoderma is one of the mushroom genera, traditionally used as popular medicinal mushrooms particularly in China, Japan and Korea for millennia to improve longevity and health (Cao et al. 2012). Hence, Ganoderma has been used as a functional food to prevent and treat many immunological diseases (De Silva et al. 2013, Tan 2015). There are many publications which show the abundance and variety of biological actions initiated by the primary metabolites of Ganoderma such as polysaccharides, proteins and triterpenes (De Silva et al. 2012a, Hapuarachchi et al. 2016a). Hence, research and development of Ganoderma is a trending topic, since the high potential to use in biotechnology. In this study, we discuss the current status of the global Ganoderma industry, cultivation, products and market.

\section{History of Ganoderma as a medicinal mushroom}

Ganoderma is called "Lingzhi", Chi-zhi" or "Rui-zhi" (auspicious herb) in China, "Reishi" ('divine Mushroom'), "Munnertake" ('10,000 year old Mushroom') or "Sachitake” in Japan and "Youngzhi" in Korea (Wagner et al. 2003, Paterson 2006). Lingzhi is viewed as the "herb of spiritual potency", "mushroom of immortality" or "Celestial Herb" and symbolizes happiness, sanctity, success, goodness and longevity (Wasser 2005, Lin 2009, De Silva et al. 2012a). The Chinese name "Lingzhi" is mainly applied to Ganoderma lucidum (Curtis) P. Karst., a woody polypore (Basidiomycota) and it has played an important role as a medicinal mushroom in Chinese and Japanese culture for at least 2000 years (Sliva 2006). Images of this mushroom can be seen often portrayed in ancient, oriental art and depictions of this fungus proliferated through Chinese literature and art (McMeekin 2004, Pegler 2002). Although 'Lingzhi' is important traditional medicine in Chinese culture for over millennia, assertions have been made that the basic concept of Lingzhi originated in India, and was an expression of "Soma", a Vedic plant (Soma-Haoma) (Pegler 2002). Time has made changes in legends and myths, and however, the "Lingzhi" name was finally assigned to a mushroom (Pegler 2002). The idea of 'Lingzhi', a mushroom with magical powers first appeared in the Qin Dynasty (221 - 207 BCE). Lingzhi was recorded in the first book which was wholly devoted to the descriptions of herbs and their medicinal values, Shen Nong Ben Cao Jing written in Han Dynasty (206 BCE-220 CE) (Wachtel-Galor et al. 2005).

Lingzhi is mentioned in a 2000-years-old poem from the Han Dynasty and earlier descriptions of the 'Mushroom of Immortality' probably refer to this species (Money 2016). As early as 800 years ago in Yuan Dynasty (A.D. 1280 - 1368) "Lingzhi" has been represented in paintings, wood carvings, carvings of jade and deer's antlers, furniture, carpet designs, balustrades, jewelry, women's hair combs, perfumes, handicrafts and many more creative artworks (Wasser \& Weis 1999). The first Chinese Pharmacopeia was written in Ming Dynasty (A.D. 1590) and Lingzhi has been recorded as a medicinal mushroom which claims several beneficial medicinal properties (Wachtel-Galor et al. 2011). This mushroom is popular in North America and Europe as one of the "artist's conk" fungi, but now it has been identified as G. applanatum. Furthermore, this has been used in the Orient as a talisman to protect a person or home against evil (Chang \& Buswell 1999). The stipe of the fruiting bodies of G. neojaponicum were cut into bead-like pieces, strung and worn round the neck of children to treat epilepsy in Malaysia by ancient tribes (Tan 2015). 


\section{Taxonomic history and controversies}

Traditional Chinese books classified Ganoderma into six species with reference to the colour of the fruiting body: Sekishi (red), Shishi (violaceous), Kokushi (black), Oushi (yellow), Hakushi (white) and Seishi (blue), and were assigned based on different triterpenoid patterns (Szedlay 2002) (Table 1). Liu (1974) compiled a monograph on Traditional Chinese Medicinal Fungi describing $G$. lucidum as "Lingzhi" in his book. Since then, G. lucidum was accepted as the scientific binomial of "Lingzhi" in many reports on Chinese edible and medicinal mushrooms (Ying et al. 1987, Mao 1998, Dai et al. 2009, Cao et al. 2012). Mycochemical and other studies reported different species numbers in the genus Ganoderma (Li et al. 2013, Yan et al. 2013, Peng et al. 2014). However, most of the species in Ganoderma have not been subjected to systematic studies (Baby et al. 2015). There are 445 records listed in Index Fungorum (2018) for Ganoderma, although Kirk et al. (2008) estimate that there are 80 species worldwide, but several are synonyms. The taxonomic situation within Ganoderma is unclear as the species and genus concepts are confused (Hapuarachchi et al. 2018), because morphologically similar members are found in Fomes, Polyporus and Tomophagus (Paterson 2006).

The traditional taxonomy of Ganodermataceae is based on its morphological traits, however, species identification has been unclear and taxonomic segregation of the genera has been controversial, since there are fundamentally different viewpoints among mycologists (Moncalvo et al. 1995, Moncalvo \& Ryvarden 1997). Some Ganoderma collections and species have been misnamed because of the presence of heterogenic forms, taxonomic obstacles and variations in the way the genus has been subdivided (Mueller et al. 2007). Hence, most taxonomists regard the current nomenclatural situation of Ganodermataceae as chaotic and poorly studied (Ryvarden 1991, Smith \& Sivasithamparam 2003, Hapuarachchi et al. 2015, Zhou et al. 2015, Thawthong et al. 2017). Accordingly, it is important to establish a combination of morphological, chemotaxonomic and molecular methods to develop a more stable taxonomy (Richter et al. 2015, Welti et al. 2015). The collections named as G. lucidum from different parts of the world are scattered in several separated lineages in phylogenetic analyses of the genus (Wang et al. 2012). The taxonomy of the G. lucidum complex has long been subjected to debate and even after many years of discussions, its taxonomy remains problematic due to many inconsistencies of phylogeny and morphology. Hence different opinions have been raised regarding the validity of its members (Yang \& Feng 2013).

\section{Ecological aspects}

Ganoderma species have a worldwide distribution in green ecosystems both in tropical and temperate geographical regions in Asia, Africa, America and Europe (Wang et al. 2012). The species of Ganoderma have a wide host range, with more than 44 species from 34 genera of plants being identified as potential hosts (Venkatarayan 1936). Plant-pathogenic and wood decaying species (Fig. 1) of Ganoderma can cause severe diseases such as stem rot, butt rot and root rot in economically important trees and perennial crops, especially in tropical countries (Coetzee et al. 2015). Ganoderma species are white rot fungi and have ecological importance in the breakdown of woody plants for nutrient mobilization. They hold effective mechanisms of lignocellulosedecomposing enzymes useful for bioenergy production and bioremediation (Hepting 1971, Adaskaveg et al. 1991, Coetzee et al. 2015, Kües et al. 2015). Root and stem rots caused by Ganoderma species result in loss of forestry yields e.g. Areca catechu (betel nut) (Singh 1991), Camillia sinensis (tea), Cocos nucifera (coconut) (Kinge \& Mih 2015), Elaeis guineensis (oil palm) (Glen et al. 2009) and Hevea brasiliensis (rubber) (Monkai et al. 2016) worldwide. Turner (1981) reported 15 species of Ganoderma from various parts of the world, such as Africa, India, Indonesia, Malaysia, North America, Papua New Guinea and Thailand as being associated with basal stem rot of oil palm, including G. applanatum, G. boninense (= G. orbiforme), G. chalceum, G. cochlear, G. lucidum, G. miniatocinctum, G. pseudoferreum (= G. philippi), G. tornatum (= G. australe), G. tropicum and G. zonatum. Ganoderma boninense is the most aggressive pathogen to cause the basal stem rot in oil palm (Turner 1981, Wong et al. 2012). Different species produce different features 
and pathogenicity. Species identification in this genus is limited causing a crucial problem for disease management (Wong et al. 2012).
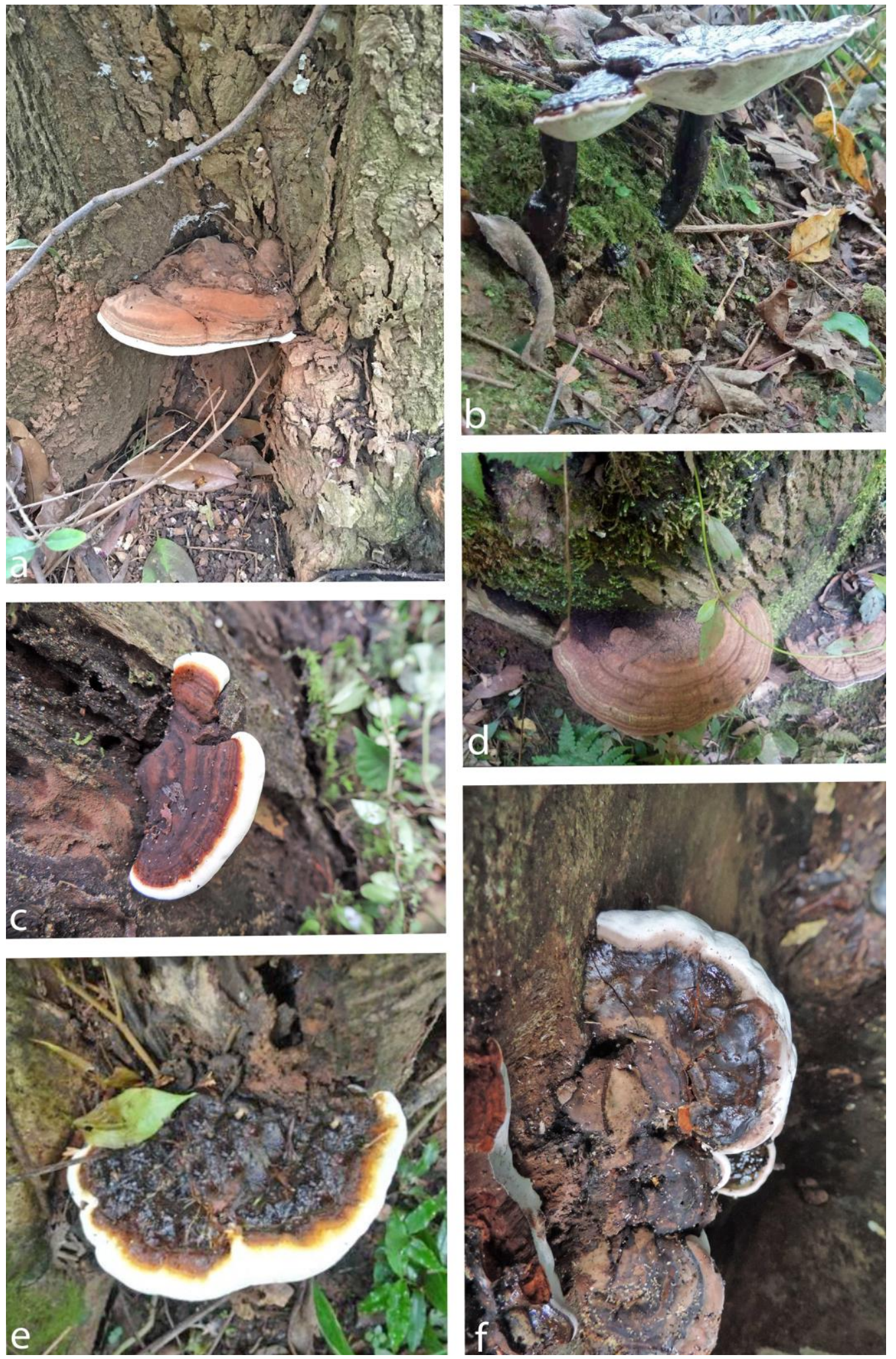

Figure 1 - Pathogenic and wood decaying Ganoderma species. a Ganoderma applanatum found in Chinese privet plant (Ligustrum lucidum) (GACP18032701). b Ganoderma sinense (GACP18032702). c Ganoderma hoehnelianum (GACP14080913). d Ganoderma donkii (GACP18032703). e Ganoderma tropicum (GACP18032704). f Ganoderma brownii (GACP18032705). (Photographs taken by TC Wen). *GACP - The Herbarium of Guizhou University (= the Original Herbarium of Guizhou Agricultural College) 


\section{Important uses of Ganoderma}

Species of Ganoderma are widely researched, because of their highly prized medicinal value, since they contain many chemical constituents with potential nutritional and therapeutic values (Hapuarachchi et al. 2016b, 2017) (Fig. 4). Ganoderma and Amauroderma include several species which possess great economic and ecological importance (Correia de Lima et al. 2014). The fruiting bodies of Ganoderma species have gained wide popular use as dietary supplements in China, Japan, North America and other regions of the world (Paterson 2006). Ganoderma has been used as a functional food to prevent and treat immunological diseases (Wang et al. 2012). Several hundreds of metabolites have been obtained from the species of this family, including G. lucidum, which is the most sought after species of the genus (Dong \& Han 2015). Polysaccharides, steroids and triterpenes as the major groups followed by alkaloids, fatty acids, glycoproteins, inorganic elements, lignin, nucleosides, nucleotides, peptides, phenols, proteins, sterols and vitamins were found in G. lucidum (Boh et al. 2007). The bioactive constituents (Table 2) are reported to be responsible for anti-cancer, anti-inflammatory, anti-tumor, anti-oxidant, immunomodulatory, immunodeficiency, anti-diabetic, anti-viral, anti-bacterial, anticonvulsant, anti-fungal, antihypertensive, anti-atherosclerotic, anti-aging, anti-androgenic, anti-hepatotoxic, radical scavenging property, neuroprotection, sleep promotion, cholesterol synthesis inhibition, hypoglycemia, inhibition of lipid peroxidation/oxidative DNA damage, hepatoprotective properties, maintenance of gut health, prevention of obesity, and stimulation of probiotics (Paterson 2006, Cao et al. 2012, De Silva et al. 2012a, b, 2013, Baby et al. 2015, Bishop et al. 2015, Liu et al. 2015b, Vyas et al. 2016).

Generally, Ganoderma species are a good source of anti-oxidant compounds (Mau et al. 2005a, b, Rawat et al. 2013), and such compounds can reduce oxidative damage by directly scavenging free radicals generated in the cell (Wong et al. 2004, Agarwal et al. 2012, Celik et al. 2014, Rajoriya et al. 2015, Obodai et al. 2017). The presence of phenolic compounds are also responsible for anti-oxidant properties in many mushrooms (Ferreira et al. 2009, Barros et al. 2008). The presence of flavonoids specifically may have detoxification, anti-inflammatory, and curing activities for various cardiovascular diseases (Le Marchand 2002). Many Ganoderma species exert remarkable anti-tumor activity (Jeong et al. 2008) due to the presence of many compounds such as triterpenes which can suppress growth and aggressiveness of cancer cells, polysaccharides that stimulate the anti-cancer response of immune cells and activate production of cytokines (Kuo et al. 2006, Sliva 2006, Smina et al. 2011), and flavonoids (Le Marchand 2002). An extract of G. lucidum inhibits distinct signalling pathways in different cancer cells (Aydemir 2002). Ganoderma lucidum has also strong activity against human prostate cancer cells since it induces apoptosis, inhibits cell proliferation, and suppresses cell migration (Stanley et al. 2005). Ganoderma lucidum showed activity against lymphoma, leukemia, and multiple myeloma cells (Muller et al. 2006). Furthermore, the methanolic extract of G. applanatum has an apoptotic antitumor activity in human colon cancer cell line (Caco-2) (Elkhateeb et al. 2018). Some Ganoderma metabolites showed also an anti-microbial activity against different pathogenic bacteria and fungi (Shikongo et al. 2013, Singh et al. 2014). Quereshi et al. (2010) reported the anti-bacterial activity of the acetone extract from fruiting bodies of G. lucidum against Staphylococcus aureus and against Pseudomonas aeruginosa. Polysaccharides extracted from G. lucidum exerted an anti-bacterial activity against Micrococcus luteus ATCC 10240 (Skalicka-Woźniak et al. 2012). Hleba et al. (2014) described the anti-microbial activity of the methanolic extracts of G. lucidum against Saccharomyces cerevisiae. Furthermore, ganodermin extracted from Ganoderma lucidum exhibited anti-fungal activity against Botrytis cinerea, Fusarium oxysporum and Physalospora piricola (Wang \& Ng 2006). Polysaccharides extracted from Ganoderma species have been reported to have anti-tumor activity (Kim et al. 1980, Miyazaki \& Nishijima 1981). Ganoderiol F and ganodermanontriol obtained from the methanol extract of the fruiting bodies of G. lucidum have anti-HIV-1 activity (El-Mekkawy et al. 1998). Eo et al. (1999) reported anti-viral activity of $G$. lucidum carpophores against herpes simplex virus type 2 (HSV-2) with low cytotoxicity to host cells in vitro. Li \& Wang (2006) described ganoderic acid extracted from G. lucidum as an anti- 
hepatitis B agent since it inhibited virus replication. Zhang et al. (2014) recorded the significant anti-viral activity of G. lucidum against enterovirus, which is the major cause of hand, foot and mouth diseases.

Ganoderma (as Lingzhi) was cultivated in a large-scale, successfully for the first time in 1969 in China (Yu \& Shen 2003) and currently, the annual sale of products derived from G. lucidum is estimated to be more than US\$ 2.5 billion in Asian countries, including China (Figs 2, 3), Japan, and South Korea (Li et al. 2013). Ganoderma sinense and G. lucidum have been listed in Chinese Pharmacopeia to prevent and treat many diseases, and Ganoderma was included in American Herbal Pharmacopoeia and Therapeutic Compendium.

Table 1 The six types of traditional Ganoderma and their uses (Szedlay 2002, Wasser 2005).

\begin{tabular}{|c|c|c|c|c|}
\hline Color & Taste & Chinese name & Japanese name & Uses \\
\hline Blue & Sour & Seishi & Aoshiba & $\begin{array}{l}\text { Improves eyesight and } \\
\text { liver function, calms } \\
\text { nerves }\end{array}$ \\
\hline Red & Bitter & Sekishi & Akashiba & $\begin{array}{l}\text { Supports internal organs; } \\
\text { sharpens memory, } \\
\text { enhances vitality }\end{array}$ \\
\hline Yellow & Sweet & Oushi & Kishiba & $\begin{array}{l}\text { Strengthens spleen } \\
\text { function }\end{array}$ \\
\hline White & $\begin{array}{l}\text { Hot (or } \\
\text { pungent) }\end{array}$ & Hakushi & Shiroshiba & $\begin{array}{l}\text { Improves lung function, } \\
\text { gives courage and strong } \\
\text { will }\end{array}$ \\
\hline Black & Salty & Kokushi & Kuroshiba & Protects kidneys \\
\hline
\end{tabular}

Table 2 Common therapeutic effects of different Ganoderma spp.

\begin{tabular}{|c|c|c|c|}
\hline $\begin{array}{l}\text { Therapeutic } \\
\text { effects }\end{array}$ & Ganoderma spp. & Major bioactive compounds & References \\
\hline \multirow[t]{11}{*}{ Anti-cancer } & G. amboinense & $\begin{array}{l}\text { Ganoderic acid X, Lanostanoid } \\
\text { triterpenes }\end{array}$ & $\begin{array}{l}\text { Li et al. } 2005, \\
\text { Hsu et al. } 2008\end{array}$ \\
\hline & G. applanatum & $\begin{array}{l}\text { Terpene (Presiccanochromenic acid, } \\
\text { Myrocin C, Sphaeropsidin D, } \\
\text { Deoxyherqueinone, Xylariacin B, } \\
\text { Trichiol C, Comazaphilone D, } \\
\text { Zeylasteral, Erinacine H, } \\
\text { Applanoxidic acid C,D, E, F,G,H }\end{array}$ & $\begin{array}{l}\text { Elkhateeb et al. } \\
2018\end{array}$ \\
\hline & G. lucidum & $\begin{array}{l}\text { Triterpenoids (Ganoderic acids, } \\
\text { Lucidumol, Lucialdehyde, Lucidenic } \\
\text { acids) }\end{array}$ & $\begin{array}{l}\text { Yuen \& Gohel } \\
2005\end{array}$ \\
\hline & & LZ-8 protein & Boh 2013 \\
\hline & & Polysaccharides, GLP-2B & $\begin{array}{l}\text { Zhang et al. } 2011 \\
\text { Huang \& Ning }\end{array}$ \\
\hline & & LZP-F3 & 2010 \\
\hline & & & Zhang et al. 2010 \\
\hline & & GLIS & Zhu et al. 2007 \\
\hline & & GIPS & Cao \& Lin 2006 \\
\hline & & GlPP & \\
\hline & G. tsugae & Crude extract of G. tsugae & Hsu et al. 2008 \\
\hline
\end{tabular}


Table 2 Continued.

\begin{tabular}{|c|c|c|c|}
\hline $\begin{array}{l}\text { Therapeutic } \\
\text { effects }\end{array}$ & Ganoderma spp. & Major bioactive compounds & References \\
\hline \multirow{3}{*}{$\begin{array}{l}\text { Anti-diabetic } \\
\text { effects }\end{array}$} & G. applanatum & Polysaccharides (PSG) & Jung et al. 2005 \\
\hline & G. atrum & Polysaccharides (PSG) & $\begin{array}{l}\text { Zhu et al. 2013, } \\
2016\end{array}$ \\
\hline & G. lucidum & $\begin{array}{l}\text { Polysaccharides, proteoglycans, } \\
\text { Proteins (LZ-8) and Triterpenoids }\end{array}$ & Ma et al. 2015 \\
\hline \multirow[t]{8}{*}{$\begin{array}{l}\text { Anti- } \\
\text { inflammatory }\end{array}$} & G. applanatum & $\begin{array}{l}\text { Ganodermycin, polysaccharide } \\
\text { components }\end{array}$ & $\begin{array}{l}\text { Jung et al. 2011, } \\
\text { Vazirian et al. } \\
2014\end{array}$ \\
\hline & G. atrum & Polysaccharide (PSG-1) & Li et al. 2017 \\
\hline & G. capense & G. capense Glycopeptide (GCGP) & Zhou et al. 2014 \\
\hline & G. colossus & Colosolactones & $\begin{array}{l}\text { El Dine et al. } \\
2009\end{array}$ \\
\hline & G. lucidum & $\begin{array}{l}\text { Ganoderic acids T-Q and lucideinic } \\
\text { acids A, D2, E2, and P }\end{array}$ & Sliva et al. 2003 \\
\hline & G. sichuanense & Lingzhilactone B & Yan et al. 2015 \\
\hline & G. sinense & Triterpenoid-enriched lipids & Yue et al. 2008 \\
\hline & G. tsugae & Water soluble polysaccharides & Ko et al. 2008 \\
\hline \multirow{8}{*}{$\begin{array}{l}\text { Anti-oxidant } \\
\text { activity }\end{array}$} & G. atrum & Polysaccharides (PSG-1) & Zhu et al. 2016 \\
\hline & G. applanatum & Exopolysaccharides & Liu et al. 2015a \\
\hline & G. capense & $\begin{array}{l}\text { Polysaccharide, designated as GCPB- } \\
1 \mathrm{~b}\end{array}$ & Jiang et al. 2016 \\
\hline & G. cochlear & $(+)$ - and (-)-cochlearols & Dou et al. 2014 \\
\hline & G. hainanense & lanostane-type triterpenoids & Li et al. $2016 b$ \\
\hline & G. lucidum & $\begin{array}{l}\text { Triterpenes, Polysaccharides, } \\
\text { polysaccharide-peptide complex and } \\
\text { phenolic component }\end{array}$ & $\begin{array}{l}\text { Mehta 2014, } \\
\text { Kana et al. } 2015\end{array}$ \\
\hline & G. sichuanense & Lingzhilactone B & Yan et al. 2015 \\
\hline & G. tsugae & Polysaccharides & Tseng et al. 2008 \\
\hline \multirow{3}{*}{$\begin{array}{l}\text { Anti- Microbial } \\
\text { Activity }\end{array}$} & G. lucidum & Polysaccharides & Mehta 2014 \\
\hline & & $\begin{array}{l}\text { Triterpenoids (Ganoderic acids, } \\
\text { Ganodermin, Ganoderic acid A, } \\
\text { Ganodermadiol, Ganodermanondiol, } \\
\text { Lucidumol B, Ganodermanontriol, } \\
\text { Ganoderic acid B and Ganolucidic } \\
\text { acid A }\end{array}$ & $\begin{array}{l}\text { Zhang et al. 2011, } \\
\text { Isaka et al. 2013, } \\
\text { Bisko \& } \\
\text { Mitropolskaya } \\
\text { 1999, }\end{array}$ \\
\hline & G. pfeifferi & Ganomycins A and B & $\begin{array}{l}\text { Mothana et al. } \\
2000\end{array}$ \\
\hline $\begin{array}{l}\text { Cardiovascular } \\
\text { problems }\end{array}$ & G. lucidum & Polysaccharides (Ganopoly) & Gao et al. 2004 \\
\hline
\end{tabular}

Ganoderma tsugae is regarded as a health food by Chinese government (Chen et al. 2016). Ganoderma lucidum products, from different parts of its fruiting bodies, mycelia or spores, are sold in the form of coffee, powder, tea, dietary supplements, spore products, drinks, syrups, tooth pastes, soaps and lotions and have been commercialized as food and drug supplements (Fig. 5) which enhance the body's immune system and improve metabolic functions (Chang \& Buswell 1999, Lai et al. 2004, Singh et al. 2013). Ganoderma lucidum was used as Bonsai products to decorate gardens, ornaments and many other art products. Awareness of Ganoderma has improved from fundamental level to artificial cultivation, large-scale cultivation and isolation of bioactive components. 

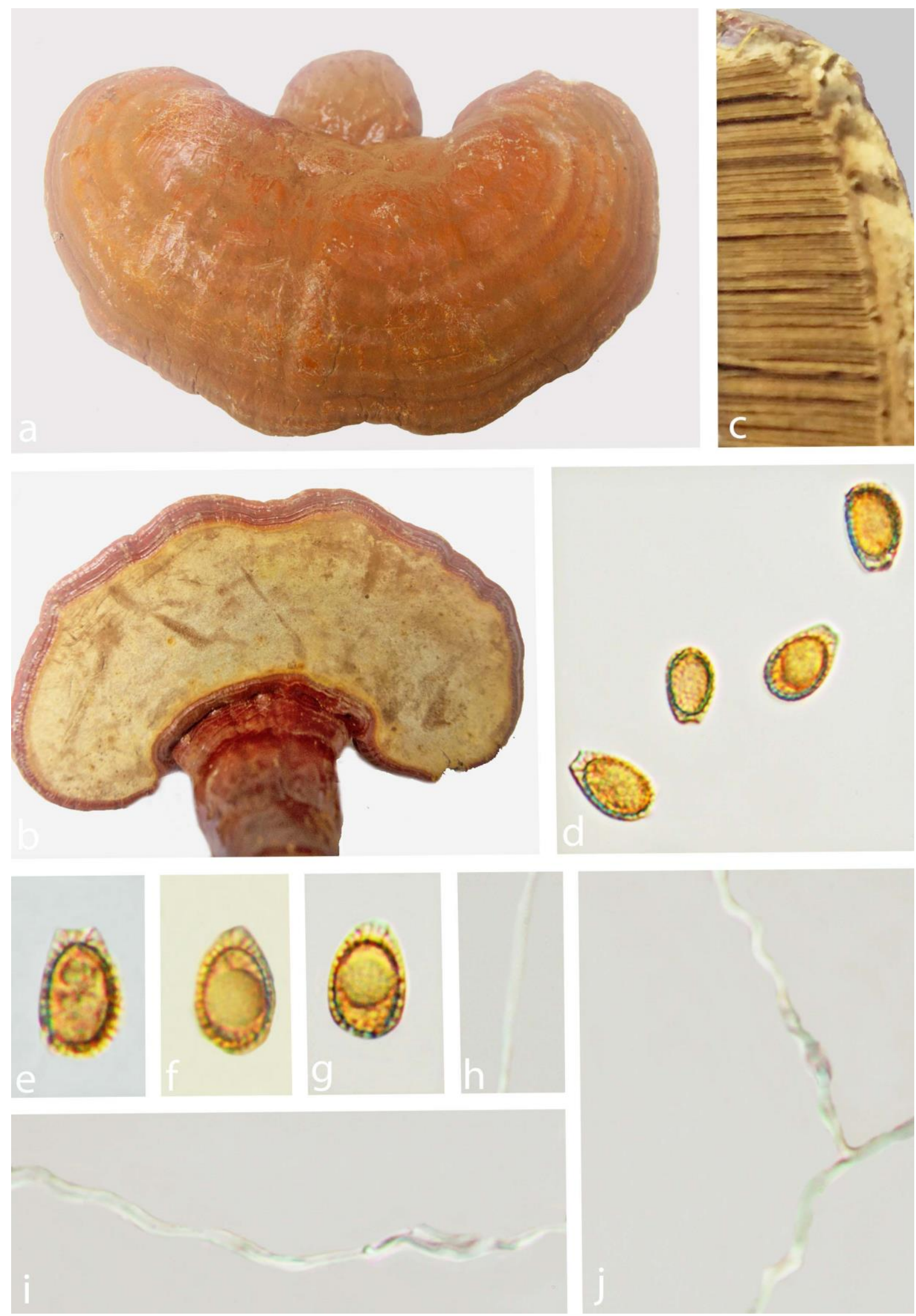

Figure 2 - Cultivated Ganoderma lingzhi species in Yunnan Province, China (GACP16091002). a Upper surface. b Lower surface. c Cut surface. d-g Spores (100x). h Generative hyphae (100x). i Skeletal hyphae (100x). j Binding hyphae (100x). Scale bars: $d-g=10 \mu \mathrm{m}, \mathrm{h}-\mathrm{j}=5 \mu \mathrm{m}$. *GACP The Herbarium of Guizhou University (= The Original Herbarium of Guizhou Agricultural College). 

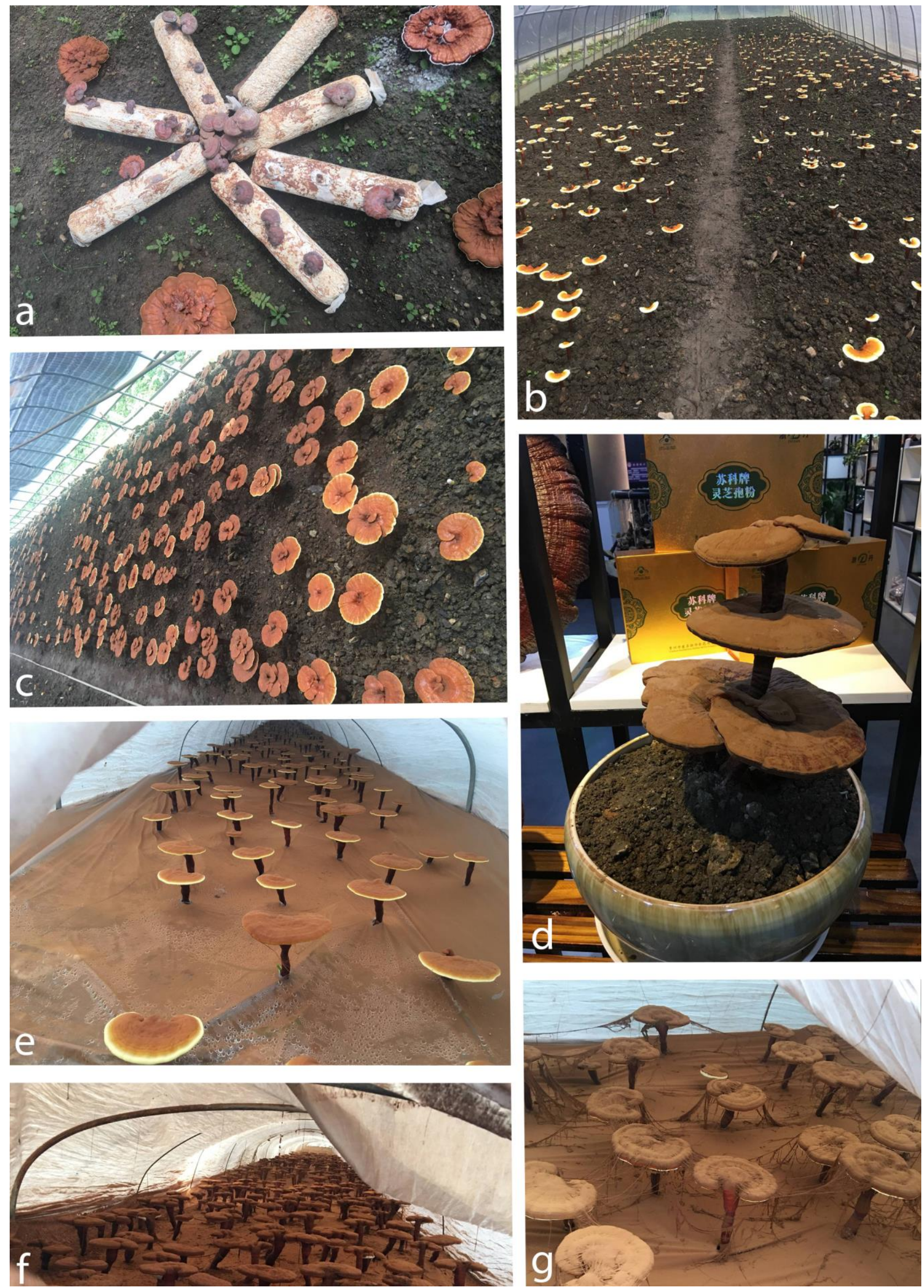

g

Figure 3 - Ganoderma cultivation in China. (Photographs taken by TC Wen) 


\section{Cosmetic products based on Ganoderma}

Ganoderma is a part of several cosmetics produced mainly in China, Korea, USA and some other Asian and European countries, many being used for skin lightening (Jiang 2015). Tyrosinase enzyme is a key enzyme in the melanin formation and Ganoderma lucidum has shown tyrosinase inhibition activity (Chien et al. 2008). Hence, many facial mask cosmetics in the market contain Ganoderma extracts which helps in skin whitening (Hyde et al. 2010). Ganoderma lucidum combined with three other plants and zinc to stimulate hair growth in human males by lowering dihydrotestosterone or prostatic hyperplasia levels (Meehan 2015). Table 3 lists common cosmetic products containing Ganoderma lucidum extracts.

\section{Traditional Chinese Medicine}

In ancient China, it was believed that Ganoderma had the power to enhance longevity and vivacity. Royalty considered it as a valuable mushroom and they used it when they were meditating (Ulbricht et al. 2010). In Traditional Chinese Medicine (TCM), Ganoderma is claimed "to replenish the energy, ease the mind, and relieve cough and asthma" (Wachtel-Galor et al. 2011). In herbal medicine, Ganoderma is used to increase energy, resist stress, or as a liver tonic (WachtelGalor et al. 2011). Modern studies associated with animal models and molecular-based research techniques have demonstrated numerous pharmacological effects supporting these claims (Hapuarachchi et al. 2016a, b, 2017). Inappropriate claims involving the efficacy of TCM are frequently made (Hui 1997). Jiaogulan (Gynostemm pentaphyllum) is mixed with G. lucidum and make "Lingzhi Jiaogulan oral liquid" which helps in relieving palpitation, shortness of breath, and insomnia (Yan 2015). There are nearly 200 medicines and compounded medicines containing Ganoderma available within China (Chen et al. 2016). Modern research revealed that triterpenoids and polysaccharides were responsible for the pharmacological effects mentioned above. However, due to the difficulty in obtaining large amounts of the pure triterpenoids and polysaccharides, double-blind clinical data of the active components are limited. No natural products or extracts from Ganoderma have been reported to enter clinical trial (Cheng et al. 2013, Hapuarachchi et al. 2017).

\section{Medicated foods and dietary supplements}

The total number of publications on Ganoderma in the world has exceeded 10,000 with 7,000 related patents. Over 1,000 Ganoderma health food products are certified by Chinese government (Chen et al. 2016). Ganoderma lucidum is used as the material of functional food in daily life such as soup, tea, wine and yoghourt (Dong \& Han 2015). This species is used with ginseng (Panax ginseng) to make soups. These soups are useful for soothing the nerves, relieving asthma, and strengthening the immune system (Zhao 2015). Ganoderma lucidum is mixed with sanqi (Panax nostoginseng) to make herbal Sanqi wine which helps to promote blood circulation and soothe nerves (Zhao 2015). Ganoderma lucidum alone or combined with other herbs such as Chinese yam (Dioscorea opposite), magnolia berry (Schisandra chinensis), and desert-broomrape (Cistanche deserticola) can be used in herbal wine for balancing the body and anti-aging process (Dong \& Han 2015). Tea is prepared by G. lucidum alone or mixed with other herbs such as Japanese honeysuckle (Lonicera japonica), Chinese hawberry (Crataegus pinnatifida) and wolfberry (Lycium barbarum) which helps in modulating immunity to keep the body in balance (Dong \& Han 2015).

\section{Cultivation}

Commercial cultivation of Ganoderma has been introduced worldwide, especially in tropical Asian countries to meet the gradually increasing demand of the mushroom as a natural medicine (Wachtel-Galor et al. 2011). Wild Ganoderma is difficult to collect and to maintain its quality. In ancient times, Ganoderma was collected from the wild and consumed only by wealthy people, but a large proportion is cultivated today for the general population. Artificial cultivation of Ganoderma was attempted in 1937 (Perumal 2009). However, the first successful cultivation of 
Ganoderma was performed in 1969 with the use of a spore separation cultivation method by a Chinese technician in the Institute of Microbiology, Chinese Academy of Sciences, Beijing (Yu \& Shen 2003). Since then, the cultivation of Ganoderma has been popular in China and other Asian countries, such as Japan and Korea (Li et al. 2016a). Traditional cultivation (since 1969) was based on inoculating one meter long natural logs without sterilization, which were then buried in a shallow trough (Pegler 2002). Most broad-leaf hardwoods can be used to cultivate Ganoderma species and logs are cut from living trees (Chen 2002). Fruiting bodies took 6-24 months to emerge, but cropping could continue for five years (Pegler 2002). Since late 1980s, new methods have been developed that use short logs (15 cm or less) (Chen 2002). Today, this method is followed by most Ganoderma natural-log growers in China, Japan and Korea (Chen \& Chen 2004). As it takes several months to produce the fruiting body, mycelia-based and culture broth-based products have been considered as methods to ensure quality control and for continuous production throughout the year (Sanodiya et al. 2009).

Different species of Ganoderma need different conditions for growth and cultivation (Mayzumi et al. 1997). There are several other methods that have been trialed to cultivate Ganoderma such as basswood cultivation (Zhang et al. 2004), sawdust cultivation and substituted cultivation. Artificial cultivation of $G$. lucidum has been achieved using substrates such as grain, sawdust, wood logs (Chang \& Buswell 1999, Wasser 2005, Boh et al. 2007), tea waste (Peksen \& Yakupoglu 2009), cotton seed husk, or residues of farm crops (Zhang \& Wang 2010), cork residues (Riu et al. 1997), sunflower seed hull (González-Matute et al. 2002), corn cobs (Ueitele et al. 2004), olive oil press cakes (Gregori \& Pohleven 2014) and wheat straw (Khajuria \& Batra 2014). Various ornamental growth forms, including antler-like structures, can be produced by altering the growing conditions, especially temperature and the carbon dioxide volume (Pegler 2002). Current methods involved in commercial production of Ganoderma, include wood log, short basswood segment, tree stump, sawdust bag, and bottle procedures (Mayzumi et al. 1997, Lin \& Zhou 1999, Erkel 2009, Chen 1999, Han et al. 2008). Natural log cultivation produces Ganoderma mushrooms with superior quality and gets best prices in the markets of Southeast Asia. However, the yield could be lower, and the production time could be little more extended than sawdust synthetic log cultivation (Chen \& Chao 1997). It is important to conserve the forests where logs are collected, and this is of significant environmental concern (Chen \& Chen 2004). Nowadays G. lucidum is not the only species in this genus grown for a commercial purpose worldwide, but also G. applanatum, G. capense, G. sinense, G. tsugae (Chen \& Chen 2004) and G. neojaponicum (Tan 2015) are cultivated in farms.

\section{Global Marketing}

Ganoderma based products have attracted a great deal of attention during the last decade in Europe, Malaysia, North America and Singapore. China, Japan and Korea are the main producers and suppliers of Ganoderma based products (Chang \& Mills 2004) (Table 4). The total Ganoderma production of Japan during 1995 was estimated approximately 500 MT. In 1997, the worldwide $G$. lucidum production was 4300 MT, and 3000 MT were from China, while 1500 MT were exported to Japan, Korea, Singapore and Taiwan. The remaining 1300 MT were produced mainly in Korea, Taiwan, Japan, Thailand, US, Malaysia, Vietnam, Indonesia and Sri Lanka (Zhou \& Gao 2002). The DXN Group in Malaysia produced 70 MT of Ganoderma and accounted for $1 \%$ of the global production in 2001 (DXN Holdings' IPO listing Reports).

The total world market for Ganoderma based natural health care products was 1628 million US dollars in 1995 (Chang \& Buswell 1999). In 2004, Ganoderma lucidum worldwide production was approximately 5000-6000 MT and more than half was produced by China (Rai 2003, Lai et al. 2004). The China Edible Fungi Association recorded that Ganoderma production in China was 36700 and 49200 MT in 2002 and 2003, respectively (Banuelos \& Lin 2009). However, there are some problems with Ganoderma based products because of low reproducibility and poor quality control. Various reasons such as seasonal variations, different soil conditions and stage of fruiting body development weaken the product quality. Hence, it is important to develop acceptable and 

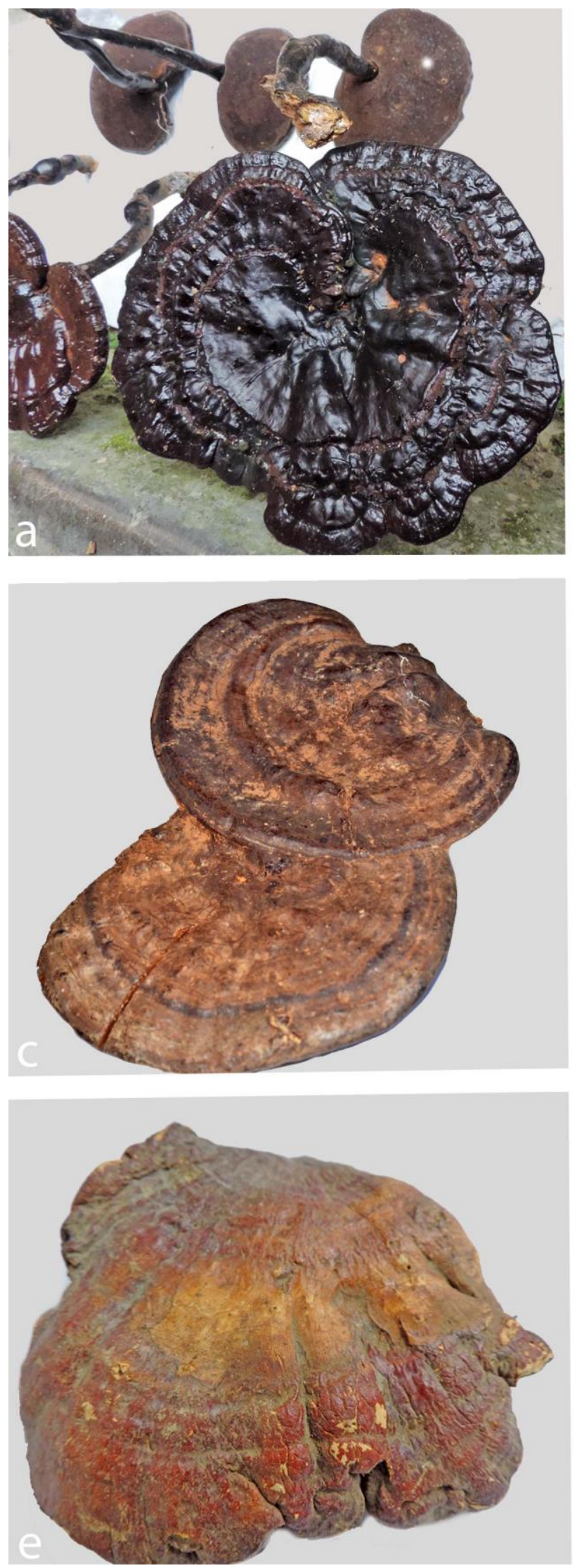
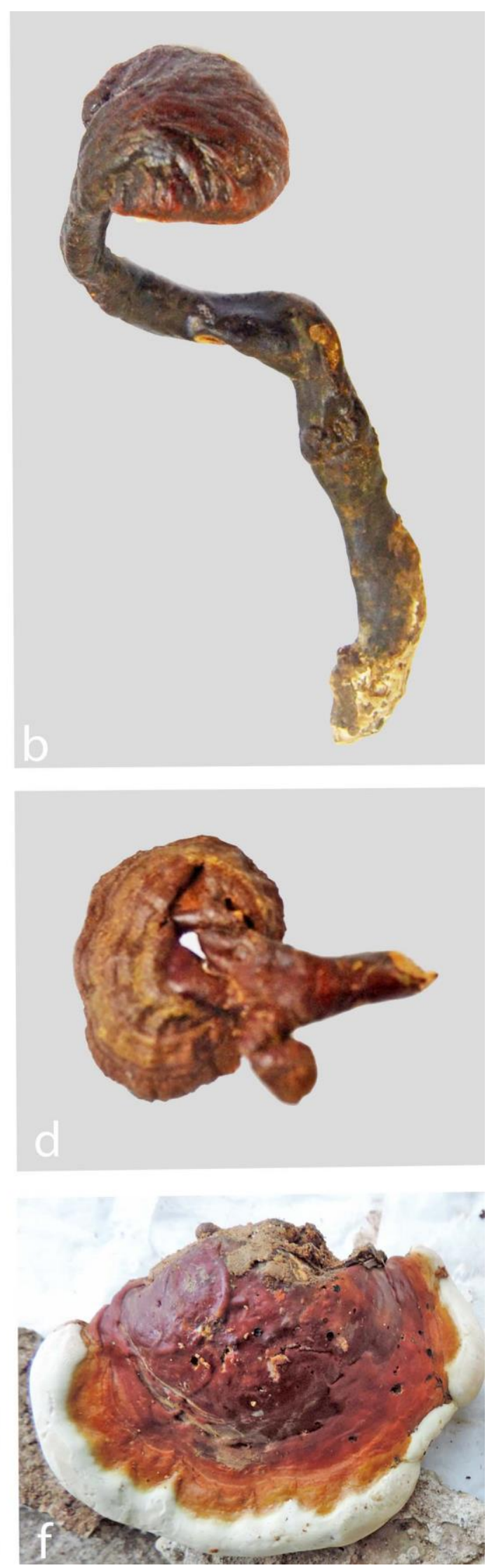

Figure 4 - Medicinally important Ganoderma species. a Ganoderma sinense (GACP14081236). b Ganoderma calidophilum (GACP15081036). c Ganoderma orbiforme (GACP1706211). d Ganoderma flexipes (GACP17102301). e Ganoderma resinaceum (GACP HNU58). f Ganoderma multiplicatum (GACP14081328). *GACP - The Herbarium of Guizhou University (= the Original Herbarium of Guizhou Agricultural College) 

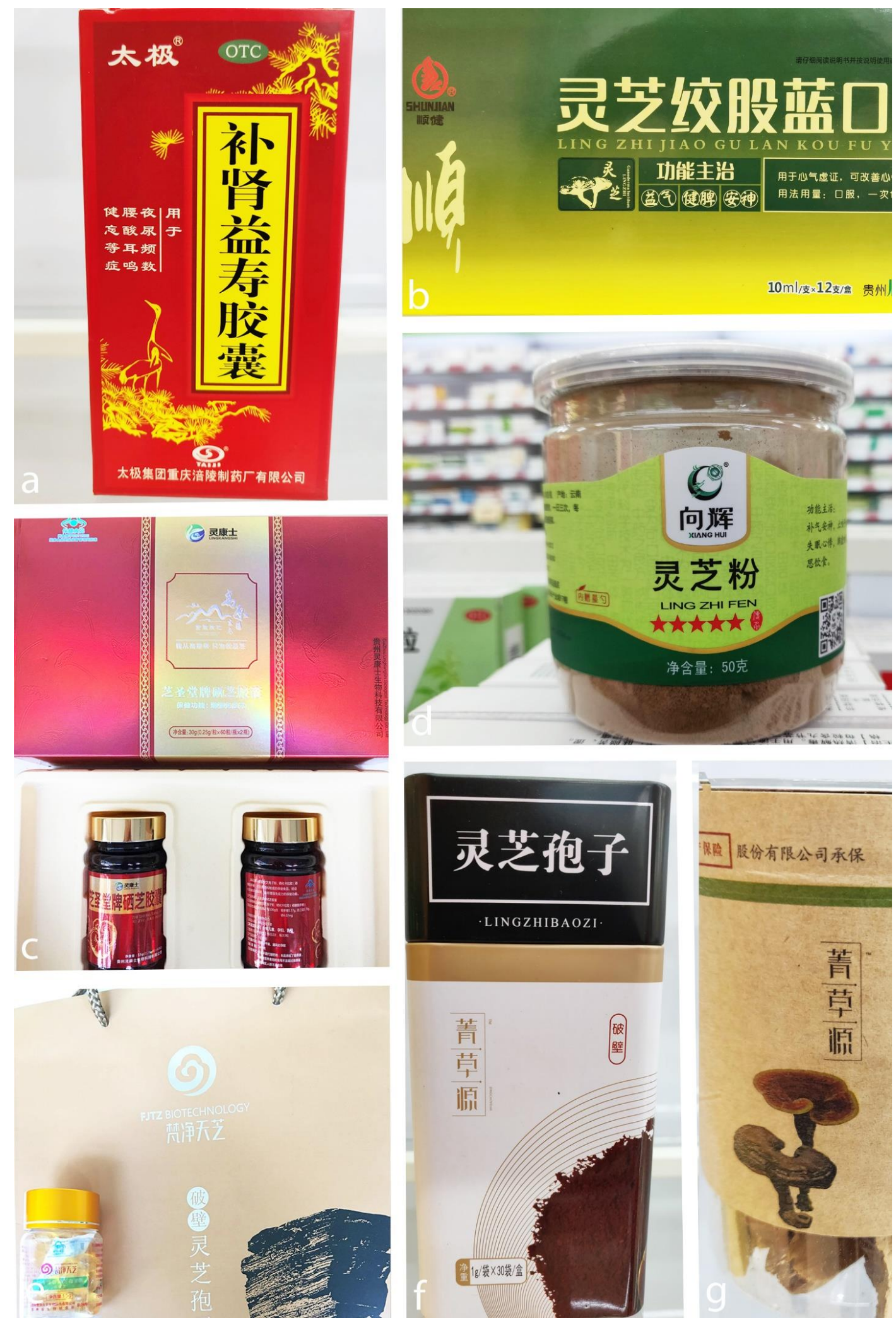

Figure 5 - Ganoderma products used as drugs and food supplements in China. a Ganoderma lucidum compound capsules (Chongqing Taiji Industry (Group) Co. Ltd). b Ganoderma lucidum syrups (Guizhou Shunjian Pharmaceutical Co. Ltd). c Ganoderma lucidum spore powder capsules enriched with Se (Guizhou Lingkangshi Biological Technology Co. Ltd). d Ganoderma lucidum spore powder (Yunnan Xianghui Pharmaceutical Co. Ltd). e Broken G. lucidum spore powder oil capsules (FGTZ Biotechnology Company). f Broken G. lucidum spore powder (Chengdu Dujiangyan Chunsheng Chinese Herbal Pieces Co. Ltd). g Ganoderma lucidum fruiting body slices (Sichuan Zibo Pharmaceutical Co. Ltd) (Photographs taken by TC Wen). 
Table 3 Cosmetic products containing Ganoderma lucidum extract and their functions.

\begin{tabular}{|c|c|c|}
\hline Product Name & Function & Reference \\
\hline $\begin{array}{l}\text { CV Skinlabs Body Repair } \\
\text { Lotion, U.S. }\end{array}$ & $\begin{array}{l}\text { Wound-healing and anti- } \\
\text { inflammatory properties }\end{array}$ & Wu et al. 2016 \\
\hline $\begin{array}{l}\text { Dr. Andrew Weil for } \\
\text { Origins Mega-Mushroom, } \\
\text { Skin Relief Face Mask, } \\
\text { U.S. }\end{array}$ & $\begin{array}{l}\text { Anti-inflammatory } \\
\text { properties }\end{array}$ & Wu et al. 2016 \\
\hline $\begin{array}{l}\text { Dr. Andrew Weil for } \\
\text { Origins Mega-Mushroom, } \\
\text { Moisturizing body Cream, } \\
\text { U.S. }\end{array}$ & Skin anti-aging & Taofiq et al. 2016 \\
\hline $\begin{array}{l}\text { DXN Ganozhi E Deep } \\
\text { Cleansing Cream, UK }\end{array}$ & $\begin{array}{l}\text { Deeply removes impurities } \\
\text { and dead cells without } \\
\text { drying skin and revitalize } \\
\text { the skin }\end{array}$ & www.ganodermalucidumproducts.com \\
\hline $\begin{array}{l}\text { DXN Ganozhi E } \\
\text { Nourishing Night Cream, } \\
\text { UK }\end{array}$ & $\begin{array}{l}\text { Improve firmness whilst } \\
\text { strengthening the skin's } \\
\text { structure }\end{array}$ & www.ganodermalucidumproducts.com \\
\hline $\begin{array}{l}\text { DXN Ganozhi E Hydrosoft } \\
\text { Toner, UK }\end{array}$ & $\begin{array}{l}\text { cleanses and minimizes } \\
\text { pores, penetrates and tones } \\
\text { skin }\end{array}$ & www.ganodermalucidumproducts.com \\
\hline $\begin{array}{l}\text { DXN Ganozhi E UV } \\
\text { defense Day Cream, UK }\end{array}$ & $\begin{array}{l}\text { Hydrates, firms and } \\
\text { moisturize and protects } \\
\text { against UV rays }\end{array}$ & www.ganodermalucidumproducts.com \\
\hline $\begin{array}{l}\text { DXN Ganozhi } \\
\text { Moisturizing Micro } \\
\text { Emulsion, Malaysia }\end{array}$ & $\begin{array}{l}\text { Hydrate and nourish the } \\
\text { skin }\end{array}$ & www.dxnmalaysia.com \\
\hline $\begin{array}{l}\text { DXN Ganozhi Lipstick, } \\
\text { Malaysia }\end{array}$ & $\begin{array}{l}\text { Hydrating lips with a } \\
\text { natural, subtle shine }\end{array}$ & www.lifeganodermaen.dxnseo.com \\
\hline $\begin{array}{l}\text { DXN Ganozhi Liquid } \\
\text { Cleanser, Malaysia }\end{array}$ & $\begin{array}{l}\text { Cleanses skin deep into the } \\
\text { pores and refreshed }\end{array}$ & www.lifeganodermaen.dxnseo.com \\
\hline $\begin{array}{l}\text { DXN Ganozhi Toner, } \\
\text { Malaysia }\end{array}$ & $\begin{array}{l}\text { Minimize skin pores while } \\
\text { leaving the skin soft and } \\
\text { hydrated }\end{array}$ & www.lifeganodermaen.dxnseo.com \\
\hline $\begin{array}{l}\text { Estée Lauder, Re-Nutriv } \\
\text { Sun Supreme Rescue } \\
\text { Serum sun care product, } \\
\text { U.S }\end{array}$ & $\begin{array}{l}\text { Triple-action repair } \\
\text { technology to enhance the } \\
\text { skin's own natural defenses } \\
\text { against the visible effects } \\
\text { of sun exposure and sun- } \\
\text { stressed skin }\end{array}$ & Taofiq et al. 2016 \\
\hline $\begin{array}{l}\text { Guangzhou Maycare } \\
\text { cosmetics, Collagen crystal } \\
\text { facial mask, China }\end{array}$ & $\begin{array}{l}\text { Skin revitalizing and } \\
\text { whitening }\end{array}$ & www.may-care.com \\
\hline $\begin{array}{l}\text { Guangzhou Bocaly Bio- } \\
\text { Tec., Ganoderma Cells } \\
\text { Repairing Anti-aging Face } \\
\text { Mask, China }\end{array}$ & $\begin{array}{l}\text { Anti-wrinkle, firming, } \\
\text { lightening, moisturizer, } \\
\text { nourishing, pigmentation } \\
\text { correctors, pore cleaner and } \\
\text { whitening. }\end{array}$ & www.vegamebeljepara.com \\
\hline
\end{tabular}


Table 3 Continued.

\begin{tabular}{|c|c|c|}
\hline Product Name & Function & Reference \\
\hline $\begin{array}{l}\text { Guangzhou Ocean } \\
\text { Cosmetic Beauty, } \\
\text { Ganoderma Moisturizing } \\
\text { Cream, China }\end{array}$ & $\begin{array}{l}\text { Acne treatment, anti- } \\
\text { aging, anti-wrinkle, dark } \\
\text { circles, firming, } \\
\text { lightening, moisturizer, } \\
\text { nourishing, skin } \\
\text { revitalizer, sunscreen, } \\
\text { whitening. }\end{array}$ & www.vegamebeljepara.com \\
\hline $\begin{array}{l}\text { Hankook Sansim Firming } \\
\text { Cream (Tan Ryuk SANG), } \\
\text { Korea }\end{array}$ & $\begin{array}{l}\text { Make skin tight and } \\
\text { vitalized }\end{array}$ & Hyde et al. 2010 \\
\hline $\begin{array}{l}\text { Julie Levin Organic skin } \\
\text { Care, Green Tea Reishi } \\
\text { Face Serum, US }\end{array}$ & $\begin{array}{l}\text { Nourish and invigorate } \\
\text { the skin }\end{array}$ & www.leafpeople.com \\
\hline $\begin{array}{l}\text { Kat Burki Form Control } \\
\text { Marine Collagen, Gel, U.K. }\end{array}$ & $\begin{array}{l}\text { Boost collagen, improve } \\
\text { elasticity and provide } \\
\text { hydration }\end{array}$ & Wu et al. 2016 \\
\hline $\begin{array}{l}\text { MAVEX, } 24 \text { hrs. Intensive } \\
\text { Cream, Hong Kong }\end{array}$ & $\begin{array}{l}\text { Stimulates cell turnover } \\
\text { formation of collagen and } \\
\text { elastin, Skin anti-aging }\end{array}$ & www.dazzlinggroup.com \\
\hline $\begin{array}{l}\text { MAVEX, Rejuvenating } \\
\text { Treatment, Hong Kong }\end{array}$ & $\begin{array}{l}\text { Anti-oxidant action and } \\
\text { deep cellular renewal. } \\
\text { Fights degenerative } \\
\text { processes and the negative } \\
\text { action of free radicals. }\end{array}$ & www.dazzlinggroup.com \\
\hline $\begin{array}{l}\text { MAVEX, Hyaluronic } \\
\text { Lifting Serum, Hong Kong }\end{array}$ & $\begin{array}{l}\text { Stimulates collagen } \\
\text { synthesis and keeps the } \\
\text { skin toned, hydrated and } \\
\text { luminous, skin anti-aging }\end{array}$ & www.dazzlinggroup.com \\
\hline $\begin{array}{l}\text { MAVEX, Beauty Secret } \\
\text { Eye Contour, Hong Kong }\end{array}$ & $\begin{array}{l}\text { skin anti-aging, Anti- } \\
\text { oedema, prevents and } \\
\text { reduces oedemas, } \\
\text { fights the formation of } \\
\text { wrinkles }\end{array}$ & www.dazzlinggroup.com \\
\hline $\begin{array}{l}\text { MAVEX, } 2 \text { in } 1 \text { Cleansing } \\
\text { Milk \& Tonic, Hong Kong }\end{array}$ & $\begin{array}{l}\text { Effectively removes } \\
\text { impurities and residues of } \\
\text { make-up, deeply purifies, } \\
\text { deeply protects and } \\
\text { moisturize the skin }\end{array}$ & www.dazzlinggroup.com \\
\hline $\begin{array}{l}\text { MAVEX, AHA/BHA } \\
\text { Peeling, Hong Kong }\end{array}$ & $\begin{array}{l}\text { Effective exfoliating, } \\
\text { keratolytic and bio- } \\
\text { stimulating properties, } \\
\text { skin anti-aging and } \\
\text { revitalized }\end{array}$ & www.dazzlinggroup.com \\
\hline $\begin{array}{l}\text { Menard Embellir, Night } \\
\text { cream, Japan }\end{array}$ & $\begin{array}{l}\text { Eliminate toxins and help } \\
\text { repair skin damage } \\
\text { associated with over } \\
\text { exposure to UV radiation } \\
\text { and free radicals }\end{array}$ & Taofiq et al. 2016 \\
\hline
\end{tabular}


Table 3 Continued.

\begin{tabular}{|c|c|c|}
\hline Product Name & Function & Reference \\
\hline $\begin{array}{l}\text { Paris Skin Institute, } \\
\text { Derma Sublime, } \\
\text { Luxurious Revitalizing } \\
\text { crème, France }\end{array}$ & $\begin{array}{l}\text { Intensely hydrate and } \\
\text { comfort dry and sensitive } \\
\text { skin }\end{array}$ & www.parisskininstitute.com \\
\hline $\begin{array}{l}\text { Paris Skin Institute, } \\
\text { Derma Sublime, La Crème } \\
\text { Supreme, France }\end{array}$ & $\begin{array}{l}\text { Nurtured skin and } \\
\text { enhanced regenerating } \\
\text { performance, moist and } \\
\text { intense hydration. }\end{array}$ & www.parisskininstitute.com \\
\hline $\begin{array}{l}\text { Paris Skin Institute, } \\
\text { Derma Sublime, Eye } \\
\text { Crème Suprême, France }\end{array}$ & $\begin{array}{l}\text { An intense rejuvenating } \\
\text { effect while reducing the } \\
\text { appearance of dark } \\
\text { circles, lines and puffiness } \\
\text { of eyes }\end{array}$ & www.parisskininstitute.com \\
\hline $\begin{array}{l}\text { Paris Skin Institute, } \\
\text { Derma Sublime, Le } \\
\text { Sérum Lifting } \\
\text { Concentrate, France }\end{array}$ & Skin anti-aging & www.parisskininstitute.com \\
\hline $\begin{array}{l}\text { Pureology NanoWorks } \\
\text { Shineluxe, France }\end{array}$ & Anti-aging and anti-fading & Hyde et al. 2010 \\
\hline $\begin{array}{l}\text { Shenzhen Hai Li Xuan } \\
\text { Technology, HailiCare } \\
\text { Skin Whitening Cream, } \\
\text { China }\end{array}$ & $\begin{array}{l}\text { Removing freckle speckle } \\
\text { and whitening }\end{array}$ & www.vegamebeljepara.com \\
\hline $\begin{array}{l}\text { Tela Beauty Organics } \\
\text { Encore Styling, Cream, } \\
\text { U.K }\end{array}$ & $\begin{array}{l}\text { Provide hair with sun } \\
\text { protection and prevent } \\
\text { color fading }\end{array}$ & Wu et al. 2016 \\
\hline $\begin{array}{l}\text { Yves Saint Laurent Temps } \\
\text { Majeur Elixir De Nuit, } \\
\text { France }\end{array}$ & Anti-aging & Hyde et al. 2010 \\
\hline $\begin{array}{l}\text { Nanjing Zhongke } \\
\text { Pharmaceuticals, } \\
\text { Ganoderma Face Cream } \\
\text { Set (Day/night cream and } \\
\text { eye gel set), China }\end{array}$ & Immune $\&$ anti-fatigue & www.vegamebeljepara.com \\
\hline
\end{tabular}

reproducible protocols for manufacturing processes to ensure high quality, standard and safe Ganoderma products (Chang \& Mills 2004). Good laboratory, agriculture, manufacturing, production and clinical practices are essential to achieve quality Ganoderma products (Chang \& Mills 2004).

Ganoderma products are divided into three types; developmental products based on Ganoderma fruiting bodies (Wasser 2011), mycelia (He 2000), and spore powder (Xie et al. 2002). A variety of Ganoderma products have been commercialized and it is estimated that at least 100 brands and over 780 products are sold in the world markets (Lai et al. 2004, Li et al. 2016a). USA is the largest market for Ganoderma and related products (Perumal 2009). Li et al. (2016a) showed China is the largest producer and exporter with a capacity over 110,000 MT/year of fruiting bodies, slices, and spore powders as most popular products among consumers. Even though China accounts for $70 \%$ of the world's production, it exports less than 5\% of total production. Most manufacturing facilities in China do not possess internationally recognized GMP (Good Manufacturing Practice) 
certifications for acceptance in international markets (Pang 2002). There are more than 100 research institutes that specialize in the study of Ganoderma, and more than 200 factories involved in the production of drugs and nutraceuticals in China. Furthermore, many patented products have been marketed upon the preparation of anti-tumor, liver function accelerant, lowering of blood pressure, hypoglycemic activity, lowering of cholesterol levels, treatment of chronic bronchitis, immunomodulator, lysozyme as antibiotic and shampoo and body shampoo (Xie et al. 2002). In the early 1980s, there were some Ganoderma based products on the international market, such as decoction, syrup, tablet, and injection liquid. In the early 1990s, 90 brands of Ganoderma products were registered and marketed internationally (Lin 2000). However, today it varies from drugs, health liquor, and Ganoderma dietary supplements to cosmetology products. These products are sold as prescription drugs in some Asian countries, however, mostly they are advertised as dietary supplements globally (Lai et al. 2004). Global consumption is estimated at several thousand tonnes, and the demand is growing swiftly (Wachtel-Galor et al. 2011). Numerous G. lucidum products, prepared from different parts of the mushroom, are currently available on the market (Chang \& Buswell 2008). However, these products do not yet fulfill the customer satisfaction.

\section{Draw backs and future trends}

A number of challenges have to be addressed regarding this industry. The systematics and taxonomy of Ganoderma species needs to be studied and confirmed. Homogeneity of products, lack of highly value-added products, poor quality and high prices are also major problems (Li et al. 2016a). The quality standard of the fungus and management of Ganoderma products must be improved and include the identification and control of the bioactive components, any hazardous and noxious substances such as heavy metals and residual pesticides and, moreover, trials are needed to develop new product formulations (Zhou et al. 2011, Hobbs 2017). Recently, a group of researchers showed that most of the Ganoderma products in USA lacked characteristic triterpenoids and contained a starch like - polysaccharide profile that was inconsistent with $G$. lucidum (Wu et al. 2017). Furthermore, it was suggested that the quality consistency of G. lucidum dietary supplements collected in USA was extremely poor and requires careful investigation (Wu et al. 2017). All companies manufacturing Ganoderma based products should be accredited according to international standards. There has been a trend and significant increase in developing natural drugs to prevent and treat many immunological diseases over the last few decades. There have been some reports of human trials using Ganoderma as a direct control agent for various diseases but scientific evidence is inconclusive (Gao et al. 2003a, b, Zhao et al. 2011, Zhou et al. 2014, Baby et al. 2015). Clinical trials were successful most of the time together with Ganoderma preparation, but more in-depth investigation and accurate scientific evidence are still required, especially for double-blind clinical data. Factors like small sample size, lack of a placebo control group, lack of information regarding long term treatment of the drug, age, patient's gender and side effects, standard method of extraction of Ganoderma, standard dosage, and number of patients treated weaken the validity of the results (Hapuarachchi et al. 2017). However, well-designed in vivo tests and randomized controlled clinical studies with Ganoderma can provide statistically significant results to confirm the efficacy and safety of Ganoderma preparations in order to incorporate Ganoderma as an integrative therapy. Clarification of active ingredients, isolation and purification of individual compounds should be carried out and this will enable the active ingredients within nutriceutical products to be measured and to understand whether the beneficial compounds in Ganoderma act synergistically or independently. Hence, it will help to explain potential synergistic effects and establish safe and beneficial dose ranges of active ingredients for each disease type. Further, standardization and quality control of Ganoderma strains, cultivation processes, extracts and commercial formulations, are needed for wide acceptance of Ganoderma as a natural product for use in the prevention and treatment of various diseases (Hapuarachchi et al. 2016b).

Breeding of new Ganoderma strains will enhance the development of strains with higher yield and resistance to diseases, which in turn will increase productivity and reduce the use of chemicals for pest control. Modern engineering technologies, such as computerized control systems 
to control environmental parameters, techniques for the production of mushrooms in new substrates, new methods for substrate sterilization and spawn preparation, will also increase the productivity of mushroom culture (Zhou et al. 2011). Ganoderma development and research helps to prevent and control environmental pollution since the production of Ganoderma creates a great amount of waste which can be consumed as animal feed, soil conditioner, mushroom recultivation, and bioremediation. Furthermore, Ganoderma cultivation is a biotechnological process that recycles lignocellulosic wastes and converts agricultural and forest wastes into useful biomass and reduces environmental pollution (Zhou et al. 2011). Effective market research on global Ganoderma industry should be carried out with information such as company profiles, product picture and specification, capacity, production, price, cost, revenue and contact information. This will help to provide current market trends and future growth expectations with respect to value and volume, technological advancement, macro economical and governing factors in the market.

Table 4 List of major Ganoderma producing companies.

\begin{tabular}{|c|c|c|}
\hline Ganoderma Company & $\begin{array}{l}\text { Country of } \\
\text { origin }\end{array}$ & Company Website \\
\hline ALPHAY & China & http://www.alphayglobal.com/ \\
\hline AMAX NUTRASOURCE & USA & http://www.amaxnutrasource.com \\
\hline BIO-BOTANICA & USA & http://www.bio-botanica.com \\
\hline BRISTOL BOTANICALS & UK & http://www.bristolbotanicals.co.uk \\
\hline DXN & Malaysia & https://www.dxn2u.com/ \\
\hline DRAGON HERBS & USA & http://www.dragonherbs.com \\
\hline GANO EXCEL & Malaysia & http://www.ganoexcel.com.my/ \\
\hline GANOLIFE & USA & http://www.ganolife.us/ \\
\hline GUXIN & China & http://www.gubaolz.com \\
\hline HANGZHOU & China & http://johnsun.en.alibaba.com \\
\hline HOKKAIDO REISHI & Japan & http://www.hokkaido-reishi.com/ \\
\hline HUAHERNHANFANG & China & http://www.hhhf.com.cn \\
\hline HUACHENGBIO & China & http://www.huachengbio.com \\
\hline JIABAO & China & http://www.lqjiabao.com \\
\hline LINKANGSHI & China & http://www.gzlzzp.com/ \\
\hline MUSHROOM SCIENCE & USA & https://mushroomscience.com \\
\hline NATUREPLUS & China & http://www.gonatureplus.com \\
\hline NAMMEX & Canada & http://www.nammex.com \\
\hline ORGANO GOLD & Canada & https://www.organogold.com/en/ \\
\hline QINGDAO DACON & China & http://www.cccme.org.cn \\
\hline RUIZHI & China & http://www.rzswkj.com \\
\hline SANLIAN & China & http://www.cn-lingzhi.com \\
\hline SERENIGY & USA & https://sites.google.com/site/serenigycoffeebusiness/home \\
\hline SHOUXIANGU & China & http://www.sxg1909.com \\
\hline SHUANG HOR & China & http://www.shuanghor.com.my/select_country.jsp \\
\hline TOTAL LIFE CHNAGES & USA & https://totallifechanges.com/ \\
\hline XIANKELAI & China & http://www.xkl-cn.com \\
\hline $\begin{array}{l}\text { XI'AN GREENA } \\
\text { BIOTECH }\end{array}$ & China & http://www.greena-bio.com \\
\hline XIANPAILINGZHI & China & http://www.shinpire.com \\
\hline
\end{tabular}


Table 4 Continued.

\begin{tabular}{lll}
\hline Ganoderma Company & $\begin{array}{l}\text { Country of } \\
\text { origin }\end{array}$ & Company Website \\
\hline XI'AN SOST & China & http://www.xasost.com \\
\hline XIANZHILOU & China & www.xianzhilou.com \\
\hline XIAN YUENSUN & China & http://www.yuensunshine.com \\
\hline XUCHANG YUANHUA & China & http://www.yamasuan.com \\
\hline YUEWEI & China & http://www.gdyuewei.cn \\
\hline YUNLE & China & http://www.hsyllz.com \\
\hline ZHENGXIN & China & http://www.taishanlingzhi.net \\
\hline ZHONGKE & China & http://www.zhongke.com \\
\hline
\end{tabular}

\section{Acknowledgements}

This work was financed by the Science and Technology Foundation of Guizhou Province ((No. [2017]2511-1) and the Science Research Foundation of Guizhou University (No. 201309). Kalani K. Hapuarachchi is grateful to HD Yang, IMMC Sanjeewa, and ID Goonasekara for their valuable comments and suggestions. K.D. Hyde thank the grants Fungal biodiversity; climate change; landcover mapping; niche modeling; Fungal biogeography; Greater Mekong Subregion" grant No. RDG6130001 and Thailands fungal diversity, solving problems and creating biotechnological products" grant No. 61201321016.

\section{References}

Adaskaveg JE, Gilbertson RL. 1988 - Basidiospores, pilocystidia, and other basidiocarp characters in several species of the Ganoderma lucidum complex. Mycologia 80, 493-507.

Adaskaveg JE, Blanchette RA, Gilbertson RL. 1991 - Decay of date palm wood by white-rot and brown-rot fungi. Canadian Journal of Botany 69, 615-629.

Agarwal K, Chakarborthy GS, Verma S. 2012 - In vitro antioxidant activity of different extract of Ganoderma lucidum. DHR International Journal of Pharmaceutical Sciences (DHR-IJPS) ISSN, 2278-8328.

Aydemir G. 2002 - Research on nutrition and cancer: the importance of the standardized dietary assessments. Asian Pacific Journal of Cancer Prevention. 3, 177-180.

Baby S, Johnson AJ, Govindan B. 2015 - Secondary metabolites from Ganoderma. Phytochemistry 114, 66-101.

Banuelos GS, Lin ZQ. 2009 - Use and development of Bio fortified Agricultural products. Boca Ratan, Florida, CRC Press 272-292.

Barros L, Cruz T, Baptista P, Estevinho L et al. 2008 - Wild and commercial mushrooms as source of nutrients and nutraceuticals. Food and Chemical Toxicology 46, 2742-2747.

Bishop KS, Kao CHJ, Xu Y, Glucinac MP et al. 2015 - From 2000 years of Ganoderma lucidum to recent developments in nutraceuticals. Phytochemistry, Special Issue: Ganoderma Phytochemistry $114,56-65$.

Bisko NA, Mitropolskaya NY. 1999 - Some biologically active substances from medicinal mushroom Ganoderma lucidum. International Journal of Medicinal Mushrooms 5, 301.

Boh B. 2013 - Ganoderma lucidum: A Potential for Biotechnological Production of Anti-Cancer and Immunomodulatory Drugs. Recent Patents on Anti-Cancer Drug Discovery 8, 255-287.

Boh B, Berovic M, Zhang J, Zhi-Bin L. 2007 - Ganoderma lucidum and its pharmaceutically active compounds. Biotechnology Annual Review 13, 265-301.

Cao QZ, Lin ZB. 2006 - Ganoderma lucidum polysaccharides peptide inhibits the growth of vascular endothelial cell and the induction of VEGF in human lung cancer cell. Life Sciences 78, 1457-1463. 
Cao Y, Yuan HS. 2013 - Ganoderma mutabile sp. nov. from southwestern China based on morphological and molecular data. Mycological Progress 12, 121-126.

Cao Y, Wu SH, Dai YC. 2012 - Species clarification of the prize medicinal Ganoderma mushroom "Lingzhi". Fungal Diversity 56, 49-62.

Celık GY, Onbaslı D, Altınsoy B, Allı H. 2014 - In vitro Antimicrobial and Antioxidant Properties of Ganoderma lucidum extracts Grown in Turkey. European Journal of Medicinal Plants. 4, 709-722.

Chang ST, Buswell JA. 1999 - Ganoderma lucidum (Curt. Fr.) P. Karst. (Aphyllophoromycetideae) - A mushrooming medicinal mushroom. International Journal of Medicinal Mushrooms 1, 139-146.

Chang ST, Buswell JA. 2008 - Safety, quality control and regulational aspects relating to mushroom nutraceuticals. Proceedings of the 6th International Conference Mushroom Biology and Mushroom Products, GAMU Gmbh, Krefeld, Germany 188-195.

Chang ST, Mills PG. 2004 - Mushrooms: Cultivation, Nutritional Value, Medicinal Effect, and environment impact. CRC Press 357-372.

Chen AW. 1999 - Cultivation of the medicinal mushroom Ganoderma lucidum (Curt.: Fr.) P. Karst. (Reishi) in North America. International Journal of Medicinal Mushrooms 1, 263-282.

Chen AW. 2002 - Natural log cultivation of the medicinal mushroom, Ganoderma lucidum (Reishi). Mushroom Growers's Newsletter 3(9), 2-6.

Chen KL, Chao DM. 1997 - Ling Zhi (Ganoderma species), in Hsu, K. T. (ed.): Chinese medicinal mycology, United Press of Beijing Medical University and Chinese United Medical University, Beijing, China. 496-517 (in Chinese).

Chen HZ, Chen JW. 2004 - A preliminary report on solid-state fermentation of Ganoderma lucidum with Radix astragali containing medium. Chinese Journal of Integrative Medicine 2, 216-218. doi: 10.3736/jcim20040320 (In Chinese).

Chen RY, Kang J, Du GH. 2016 - Construction of the quality control system of Ganoderma Products. Edible and medicinal mushrooms 24(6), 339-344.

Cheng CR, Ding J, Yang Y, Guan SH et al. 2013 - Recent progress on the chemical constituents of genus Ganoderma. Natural Product Research and Development b12, 128-134.

Chien CC, Tsai ML, Chen CC, Chang SJ et al. 2008 - Effects on tyrosinase activity by the extracts of Ganoderma lucidum and related mushrooms. Mycopathologia 166, 117-120.

Coetzee MP, Marincowitz S, Muthelo VG, Wingfield MJ. 2015 - Ganoderma species, including new taxa associated with root rot of the iconic Jacaranda mimosifolia in Pretoria, South Africa. IMA Fungus 6, 249-256.

Correia de Lima N, Jr, Baptista Gibertoni T, Malosso E. 2014 - Delimitation of some neotropical laccate Ganoderma (Ganodermataceae): molecular phylogeny and morphology. Revista de Biología Tropical 62, 1197-1208.

Costa-Rezende DH, Robledo GL, Goes-Neto A, Reck MA et al. 2017 - Morphological reassessment and molecular phylogenetic analyses of Amauroderma s. lat. raised new perspectives in the generic classification of the Ganodermataceae family. Persoonia 39, 254 269.

Dai YC, Cui BK, Yuan HS, Li BD. 2007 - Pathogenic wood-decaying fungi in China. Forest Pathology 37, 105-120.

Dai YC, Yang ZL, Cui BK, Yu CJ et al. 2009 - Species diversity and utilization of medicinal mushrooms and fungi in China. International Journal of Medicinal Mushrooms 11, 287-302.

De Silva DD, Rapior S, Fons F, Bahkali AH et al. 2012a - Medicinal mushrooms in supportive cancer therapies: an approach to anti-cancer effects and putative mechanisms of action. Fungal Diversity. 55, 1-35.

De Silva DD, Rapior S, Hyde KD, Bahkali AH. 2012b - Medicinal mushrooms in prevention and control of diabetes mellitus. Fungal Diversity 56, 1-29. 
De Silva DD, Rapior S, Sudarman E, Stadler M et al. 2013 - Bioactive metabolites from macrofungi: ethnopharmacology, biological activities and chemistry. Fungal Diversity 62, 140.

Dong C, Han Q. 2015 - Ganoderma lucidum (Lingzhi, Ganoderma): Fungi, algae, and other materials. In: Liu Y, Wang Z, Zhang J. (Eds.) Dietary Chinese Herbs Chemistry: Pharmacology and Clinical Evidence Springer, London 759-765.

Dou M, Di L, Zhou LL, Yan YM et al. 2014 - Cochlearols A and B, Polycyclic Meroterpenoids from the fungus Ganoderma cochlear that have renoprotective activities. Organic letters 16, 6064-6067.

DXN Holdings' IPO listing Reports. Spire Research Sdn Bhd 1-15. https://www.spireresearch.com/wp-content/uploads/2012/03/IPO-prospectus-market-reportfor-herbal-product-industry-in-Malaysia.pdf.

El Dine RS, El Halawany AM, Ma CM, Hattori M. 2009 - Inhibition of the dimerization and active site of HIV-1 protease by secondary metabolites from the Vietnamese mushroom Ganoderma colossum. Journal of Natural Products 72, 2019-2023.

Elkhateeb WA, Zaghlol GM, El-Garawani IM, Ahmed EF et al. 2018 - Ganoderma applanatum secondary metabolites induced apoptosis through different pathways: In vivo and in vitro anticancer studies. Biomedicine \& Pharmacotherapy, 101, 264-277.

El-Mekkawy S, Meselhy MR, Nakamura N, Tezuka Y et al. 1998 - Anti-HIV-1 and anti-HIV-1protease substances from Ganoderma lucidum. Phytochemistry 49, 1651-1657.

Eo S, Kim Y, Lee C, Han S. 1999 - Antiviral activities of various water and methanol soluble substances isolated from Ganoderma lucidum. Journal of Ethnopharmacology 68, 129-136.

Erkel EI. 2009 - The effect of different substrate mediums on yield of Ganoderma lucidum (Fr.) Karst. Journal of Food Agriculture and Environment 7, 841-844.

Ferreira IC, Barros L, Abreu RM. 2009 - Antioxidants in Wild Mushrooms. Current Medical Chemistry 16, 1543-1560.

Gao Y, Zhou S, Huang M, Xu A. 2003a - Antibacterial and antiviral value of the Genus Ganoderma P. Karst. Species (Aphyllophoromycetideae): A review. International Journal of medicinal mushrooms 5, 235246. doi: 10.1615/InterJMedicMush.v5.i3.20.

Gao Y, Zhou S, Jiang WQ, Huang M et al. 2003b - Effects of Ganopoly (a Ganoderma lucidum polysaccharide extract) on immune functions in advanced-stage cancer patients. Immunological Investigations 32, 201-215. doi: 10.1081/IMM-120022979.

Gao H, Chan E, Zhou F. 2004 - Immunomodulating activities of Ganoderma, a mushroom with medicinal properties. Food Reviews International 20, 123-161. doi: doi.org/10.1081/FRI120037158.

Glen M, Bougher NL, Francis AA, Nigg SQ et al. 2009 - Ganoderma and Amauroderma species associated with root-rot disease of Acacia mangium plantation trees in Indonesia and Malaysia. Australasian Plant Pathology 38, 345-356.

González-Matute R, Figlas D, Devalis R, Delmastro S et al. 2002 - Sunflower seed hulls as a main nutrient source for cultivating Ganoderma lucidum. Micología Aplicada International. 14, $19-24$.

Gregori A, Pohleven A. 2014 - Cultivation of three medicinal mushroom species on olive oil press cakes containing substrates. Acta Agriculturae Solvonica. 103, 49-54. doi: 10.14720/aas.2014.103.1.05.

Hapuarachchi KK, Wen TC, Deng CY, Kang JC et al. 2015 - Mycosphere Essays 1: Taxonomic confusion in the Ganoderma lucidum species complex. Mycosphere 6, 542-559. doi: 10.5943/mycosphere/6/5/4.

Hapuarachchi KK, Wen TC, Jeewon R, Wu XL et al. 2016a - Mycosphere Essays 7: Ganoderma lucidum - are the beneficial anti-cancer properties substantiated? Mycosphere 7, 305-332. doi: 10.5943/mycosphere/7/3/6. 
Hapuarachchi KK, Wen TC, Jeewon R, Wu XL et al. 2016b - Mycosphere Essays 15: Ganoderma lucidum - are the beneficial medical properties substantiated? Mycosphere 7, 687-715. doi: 10.5943/mycosphere/7/6/1.

Hapuarachchi KK, Cheng CR, Wen TC, Jeewon R et al. 2017 - Mycosphere Essays 20: Therapeutic potential of Ganoderma species: Insights into its use as traditional medicine. Mycosphere 8, 1653-1694. doi: 10.5943/mycosphere/8/10/5.

Hapuarachchi KK, Karunarathna SC, Raspé O, De Silva KHWL et al. 2018 - High diversity of Ganoderma and Amauroderma (Ganodermataceae, Polyporales) in Hainan Island, China. Mycosphere 9(5), 931-982. doi 10.5943/mycosphere/9/5/1

Han SH, Su CA, Fan AL, Xu SS. 2008 - Cultivation utilization and development of edible fungi in China. Edible Fungi of China. 27, 3-5 (In Chinese).

He H. 2000 - Research advances and prospect on submerged fermentation technology of Ganoderma lucidum. Primary Journal of Chinese Materials and Medicine 14, 48-49 (In Chinese).

Hepting GH. 1971 - Diseases of forest and shade trees of the United States. US Department of Agriculture, Agricultural Handbook 386, 1-658.

Hleba L, Vuković, Petrová J, Kačániová M. 2014 - Antimicrobial Activity of Crude Methanolic Extracts from Ganoderma lucidum and Trametes versicolor. Animal Science and Biotechnologies 47, 89-93.

Hobbs C. 2017 - Medicinal Fungi Chemistry, Activity, and Product Assurance. HerbalGram 113, $46-61$.

Huang SQ, Ning ZX. 2010 - Extraction of polysaccharide from Ganoderma lucidum and its immune enhancement activity. International Journal of Biological Macromolecules 47, 336341.

Hui KK. 1997 - Is there a role for Traditional Chinese Medicine? [letter] Journal of the American Medical Association 277, 714. doi: 10.1001/jama.1997.03540330036029.

Hsu CC, Lin KY, Wang ZH, Lin WL et al. 2008 - Preventive effect of Ganoderma amboinense on acetaminophen-induced acute liver injury. Phytomedicine 15, 946-950.

Hyde KD, Bahkali AH, Moslem MA. 2010 - Fungi - An unusual source for cosmetics. Fungal Diversity 43, 1-9.

Index Fungorum. 2018 - http://www.indexfungorum.org (accessed 18 September 2018).

Isaka M, Chinthanom P, Kongthong S, Srichomthong K et al. 2013 - Lanostane triterpenes from cultures of the Basidiomycete Ganoderma orbiforme BCC 22324. Phytochemistry 87, 133139.

Jeong YT, Yang BK, Jeong SC, Kim SM et al. 2008 - Ganoderma applanatum: A Promising Mushroom for Antitumor and Immunomodulating Activity. Phytotherapy Research 22, 614619.

Jong SC, Birmingham JM. 1992 - Medicinal benefits of the mushroom Ganoderma. Advances in Applied Microbiology 37, 101-134.

Jiang J, Kong F, Li N, Zhang D et al. 2016 - Purification, structural characterization and in vitro antioxidant activity of a novel polysaccharide from Boshuzhi. Carbohydrate Polymers 147, 365-371. doi: 10.1016/j.carbpol.2016.04.001.

Jiang L. 2015 - Ganoderma lucidum (Reishi Mushroom): Potential Application as Health Supplement and Cosmeceutical Ingredient. Global Journal for Research Analysis 4, 124-125. doi: $10.15373 / 22778160$.

Jung SH, Lee YS, Shim SH, Lee S et al. 2005 - Inhibitory effects of Ganoderma applanatum on rat lens aldose reductase and sorbitol accumulation in streptozotocin-induced diabetic rat tissues. Phytotherapy Research 19, 477-480.

Jung M, Liermann JC, Opatz T, Erkel G. 2011 - Ganodermycin, a novel inhibitor of CXCL10 expression from Ganoderma applanatum. Journal of Antibiotics 64, 683-686. doi: 10.1038/ja.2011.64. 
Kana Y, Chen T, Wu Y, Wu J. 2015 - Antioxidant activity of polysaccharide extracted from Ganoderma lucidum using response surface methodology. International Journal of Biological Macromolecules 72, 151-157.

Karsten PA .1881 - Enumeralio boletinearum et polypore arum fennicarum, systemate novo dispositarum. Revue de Mycologie 3, 16-19.

Khajuria R, Batra P. 2014 - Supplementation of nitrogen source in wheat straw for improving cellulolytic potential of Ganoderma lucidum. International Journal of Pharma and Bio Sciences 5, 90-99.

Kim BK, Chung HS, Chung KS, Yang MS. 1980 - Studies on the antineoplastic components of Korean basidiomycetes. Korean Journal of Mycology 8, 107-113.

Kinge TR, Mih AM. 2015 - Diversity and distribution of species of Ganoderma in South Western Cameroon. Journal of Yeast and Fungal Research. 6 (2), 17-24.

Kirk PM, Cannon PF, David JC, Stalpers JA. 2008 - Ainsworth and Bisby's Dictionary of the fungi. 10th Edition. CABI Publishing 771.

Ko HH, Hung CF, Wang JP, Lin CN. 2008 - Anti-inflammatory triterpenoids and steroids from Ganoderma lucidum and G. tsugae. Phytochemistry 69, 234-249.

Kües U, Nelson DR, Liu C, Yu GJ et al. 2015 - Genome analysis of medicinal spp. with plantpathogenic and saprotrophic life-styles. Phytochemistry 114, 18-37. doi: doi.org/10.1016/j.phytochem.2014.11.019.

Kuo MC, Weng CY, Ha CL, Wu MJ. 2006 - Ganoderma lucidum mycelia enhance innate immunity by activating NF-kappaB. Journal of Ethnopharmacology 103(2), 217-222.

Lai T, Gao Y, Zhou SF. 2004 - Global marketing of medicinal Ling Zhi mushroom Ganoderma lucidum (W.Curt:Fr.) Lloyd (Aphyllophoromycetideae) products and safety concerns. International Journal of Medicinal Mushrooms 6, 189-194.

Le Marchand L. 2002 - Cancer preventive effects of flavonoids - a review. Biomedical Pharmacotherapy 56, 296-301.

Li CH, Chen PY, Chang UM, Kan LS et al. 2005 - Ganoderic acid X, a lanostanoid triterpene, inhibits topoisomerases and induces apoptosis of cancer cells. Life Sciences 77, 252-265.

Li J, Zhang J, Chen H, Chen X et al. 2013 - Complete Mitochondrial Genome of the Medicinal Mushroom Ganoderma lucidum. Plos one 8, 72038.

Li S, Dong C, Wen HA, Liu X. 2016 - Development of Ling-zhi industry in China-emanated from the artificial cultivation in the Institute of Microbiology, Chinese Academy of Sciences (IMCAS). Mycology 7, 74-80.

Li W, Lou LL, Zhu JY, Zhang JS et al. 2016b - New lanostane-type triterpenoids from the fruiting body of Ganoderma hainanense. Fitoterapia 115, 24-30.

Li WJ, Li L, Zhen WY, Wang LF et al. 2017 - Ganoderma atrum polysaccharide ameliorates ROS generation and apoptosis in spleen and thymus of immunosuppressed mice. Food and Chemical Toxicology 99, 199-208.

Li YQ, Wang SF. 2006 - Anti-hepatitis B activities of ganoderic acid from Ganoderma lucidum. Biotechnology letters, 28, 837-841.

Lin J, Zhou XW. 1999 - Artificial cultivation of organizational separation of Ganoderma lucidum. Edible Fungi 2, 10-11 (In Chinese).

Lin SC. 2000 - Beijing, China: Chinese Agricultural Press; Medicinal Fungi of China-Production and Products Development.

Lin ZB. 2009 - Lingzhi: from mystery to science. Peking University Medical Press, Beijing 1-162.

Liu B. 1974 - The Chinese medical fungi. Shanxi Peoples Press, Taiyuan 1-196.

Liu H, Hou XG, Zhao JH, HE L. 2015a - Liquid Fermentation of Ganoderma applanatum and Antioxidant Activity of Exopolysaccharides. The Open Biomedical Engineering Journal. 9, 224-227.

Liu YH, Lin YS, Lin KL, Lu YL et al. 2015b - Effects of hot-water extracts from Ganoderma lucidum residues and solid-state fermentation residues on prebiotic and immune-stimulatory 
activities in vitro and the powdered residues used as broiler feed additives in vivo. Botanical Studies 56, 17.

Ma HT, Hsieh JF, Chen ST. 2015 - Anti-diabetic effects of Ganoderma lucidum. Phytochemistry $114,109-113$.

Mao XL. 1998 - Economic fungi of China. Science Press, Beijing. 1-762(in Chinese).

Mau JL, Tsai SY, Tseng YH, Huang SJ. 2005a - Antioxidant properties of hot water extracts from Ganoderma tsugae Mur-rill. LWT - Food Science and Technology 38, 589-597.

Mau JL, Tsai SY, Tseng YH, Huang SJ. 2005b - Antioxidant properties of methanolic extracts from Ganoderma tsugae. Food Chemistry 93, 641-649.

Mayzumi F, Okamoto H, Mizuno T. 1997 - Cultivation of Reishi (Ganoderma lucidum). Food Reviews International 13, 365-382.

McMeekin D. 2004 - The perception of Ganoderma lucidum in Chinese and Western culture. Mycologist 18, 165-169.

Meehan K. 2015 - Composition to Promote Hair Growth in Humans. U.S. Patent US9144542, 29 September.

Mehta S. 2014 - Studies on genetic variability and bioactive molecules production by Ganoderma species. Ph.D. Thesis, Shoolini University of Biotechnology and Management Sciences Bajhol, Solan (HP), India.

Miyazaki T, Nishijima M. 1981 - Studies on fungal polysaccharides. XXVII. Structural examination of a water-soluble, antitumor polysaccharide of Ganoderma lucidum. Chemical and Pharmaceutical Bulletin 29, 3611-3616.

Moncalvo JM, Ryvarden L. 1997 - A nomenclatural study of the Ganodermataceae Donk. Fungi flora 10, 1-114.

Moncalvo JM, Wang HF, Hseu, RS. 1995 - Gene phylogeny of the Ganoderma lucidum complex based on ribosomal DNA sequences. Comparison with traditional taxonomic characters. Mycological Research 99, 1489-1499.

Money NP. 2016 - Are mushrooms medicinal? Fungal Biology. 120, 449-453. doi: doi.org/10.1016/j.funbio.2016.01.006.

Monkai JM, Hyde KD, Xu JC, Mortimer PE. 2016 - Diversity and Ecology of soil fungal communities in rubber plantation. Fungal Biology Reviews 31, 1-11.

Mothana RAA, Jansen R, Jülich WD, Lindequist U. 2000 - Ganomycin A and B, new antimicrobial farnesyl hydroquinones from the basidiomycete Ganoderma pfeifferi. Journal of Natural Products 63, 416-418.

Muller CI, Kumagai T, O'Kelly J, Seeram NP et al. 2006 - Ganoderma lucidum causes apoptosis in leukemia, lymphoma and multiple myeloma cells. Leukemia Research 30, 841-848.

Mueller GM, Shcmit JP, Leacock PR, Buyck B et al. 2007 - Global diversity and distribution of macro fungi. Biodiversity and Conservation 16, 37-48.

Obodai M, Narh Mensah DL, Fernandes Â, Kortei NK et al. 2017 - Chemical Characterization and Antioxidant Potential of Wild Ganoderma Species from Ghana. Molecules, 22(2), 196. doi: 10.3390/molecules22020196

Pang A. 2002 - Traditional Medicine in China, World Market Research Centre (www.wmrc.com)

Paterson RRM. 2006 - Ganoderma a therapeutic fungal bio factory. Phytochemistry 67, 19852001.

Pegler DN. 2002 - Useful fungi of the world: the Ling-zhi - the mushroom of immortality. Mycologist 16, 100-101.

Peksen A, Yakupoglu G. 2009 - Tea waste as a supplement for the cultivation of Ganoderma lucidum. World Journal of Microbiology and Biotechnology 25, 611-618. doi:10.1007/s11274-008-9931-z.

Peng XR, Liu JQ, Wang CF, Li XY et al. 2014 - Hepatoprotective effects of triterpenoids from Ganoderma cochlear. Journal of Natural Products 77, 737-743.

Perumal K. 2009 - Indigenous technology on organic cultivation of Reishi. AMM Murugappa Chettiar Research Centre 1-12. 
Pilotti CA. 2005 - Stem rots of oil palm caused by Ganoderma boninense: Pathogen biology and epidemiology. Mycopathologia 159, 129-137.

Pilotti CA, Sanderson FR, Aitken AB, Armstrong W. 2004 - Morphological variation and host range of two Ganoderma species from Papua New Guinea. Mycopathologia 158, 251-265.

Quereshi S, Pandey A, Sandu, S. 2010 - Evaluation of Antibacterial Activity of Different Ganoderma lucidum Extract. People's Journal of Scientific Research 3, 1-5.

Rai RD. 2003 - Successful cultivation of the medicinal mushroom Reishi, Ganoderma lucidum in India. Mushroom Research 12, 87-91.

Rajoriya A, Tripathy S, Gupta N. 2015 - In vitro antioxidant activity of selected Ganoderma species found in Odisha, India. Tropical Plant Research 2, 72-77.

Rawat A, Mohsin M, Negi PS, Sah AN et al. 2013 - Evaluation of polyphenolic contents and antioxidant activity of wildy collected Ganoderma lucidium from Himalayan hills of India. Asian journal of plant science and research 3, 85-90.

Richter C, Wittstein K, Kirk MP, Stadler M. 2015 - An assessment of the taxonomy and chemotaxonomy of Ganoderma. Fungal Diversity 71, 1-15. doi: 10.1007/s13225-014-0313-6.

Riu H, Roig G, Sancho J. 1997 - Production of carpophores of Lentinus edodes and Ganoderma lucidum grown on cork residues. Microbiologia SEM 13, 185-92.

Ryvarden L. 1991 - Genera of polypores - Nomenclature and taxonomy. Fungiflora, Oslo.

Sanodiya BS, Thakur GS, Baghel RK, Prasad GB et al. 2009 - Ganoderma lucidum: a potent pharmacological macrofungus. Current Pharmaceutical Biotechnology 10, 717-742.

Shikongo LT, Chimwamurombe PM, Lotfy HR. 2013 - Antimicrobial screening of crude extracts from the indigenous Ganoderma lucidum mushrooms in Namibia. African Journal of Microbiology Research 7(40), 4812-4816.

Singh G. 1991 - Ganoderma-The scourge of oil palms in the coastal areas. Planter, 67, 421-444.

Singh J, Gupta V, Malviya S, Ahrwar B. 2014 - In-vitro Evaluation of Antimicrobial Activity of Ganoderma lucidum. International Journal of Advanced Research 2, 460-466.

Singh SK, Doshi A, Pancholy A, Pathak R. 2013 - Biodiversity in wood-decay macro-fungi associated with declining arid zone trees of India as revealed by nuclear rDNA analysis. European Journal of Plant Pathology. 136, 373-382.

Skalicka-Woźniak K, Szypowski J, Łoś R, Siwulski M et al. 2012 - Evaluation of polysaccharides content in fruit bodies and their antimicrobial activity of four Ganoderma lucidum (W Curt.: Fr.) P. Karst. strains cultivated on different wood type substrates. Acta Societatis Botanicorum Poloniae 81, 17.

Sliva D. 2006 - Ganoderma lucidum in cancer research. Leukemia Research 30, 767-768.

Sliva D, Sedlak M, Slivova V, Valachovicova T et al. 2003 - Biologic activity of spores and dried powder from Ganoderma lucidum for the inhibition of highly invasive human breast and prostate cancer cells. The Journal of Alternative and Complementary Medicine 9, 491-497.

Smina TP, Mathew J, Janardhanan KK, Devasagayam TP. 2011 - Antioxidant activity and toxicity profile of total triterpenes isolated from Ganoderma lucidum (Fr.) P. Karst occurring in South India. Environmental Toxicology and Pharmacology 32, 438-446.

Smith BJ, Sivasithamparam K. 2000 - Internal transcribed spacer ribosomal DNA sequence of five species of Ganoderma from Australia. Mycological Research 104, 943-951.

Smith BJ, Sivasithamparam K. 2003 - Morphological studies of Ganoderma (Ganodermataceae) from the Australian and Pacific regions. Australasian Systematic Botany 16, 487-503.

Stanley G, Harvey K, Slivova V, Jiang J, Sliva D. 2005 - Ganoderma lucidum suppresses angiogenesis through the inhibition of secretion of VEGF and TGF-beta1 from prostate cancer cells. Biochemical and Biophysical Research Communications 330, 46-52.

Szedlay G. 2002 - is the widely used medicinal fungus the Ganoderma lucidum (fr.) karst. sensu stricto? Acta Microbiologica et Immunologica Hungarica 49, 235-243. 
Tan WC. 2015 - Ganoderma neo-japonicum Imazeki revisited: Domestication study and antioxidant properties of its basidiocarps and mycelia. Scientific Reports 5, 12515. doi: $10.1038 /$ srep12515.

Taofiq O, González-Paramás AM, Martins A, Barreiro MF et al. 2016 - Mushrooms extracts and compounds in cosmetics, cosmeceuticals and nutricosmetics - A review. Industrial Crops and Products 90, 38-48.

Thawthong A, Hapuarachchi KK, Wen TC, Raspé O et al. 2017 - Ganoderma sichuanense (Ganodermataceae, Polyporales) new to Thailand. MycoKeys 22, 27-43. https://doi.org/10.3897/ mycokeys.22.13083.

Tseng YH, Yang JH, Mau JL. 2008 - Antioxidant properties of polysaccharides from Ganoderma tsugae. Food Chemistry 107, 732-738.

Turner PD. 1981 - Oil Palm Diseases and Disorders. Oxford University Press 88-110.

Ueitele ISE, Kadhila Muandingi NP, Matundu N. 2014 - Evaluating the production of Ganoderma mushroom on corn cobs. African Journal of Biotechnology 13, 2215-2219.

Ulbricht C, Isaac R, Milkin T, Poole E et al. 2010 - An evidence-based systematic review of stevia by the Natural Standard Research Collaboration. Cardiovascular \& Hematological Agents in Medicinal Chemistry 8, 113-127.

Vazirian M, Dianat S, Manayi A, Ziari R et al. 2014 - Anti-inflammatory effect, total polysaccharide, total phenolics content and antioxidant activity of the aqueous extract of three basidiomycetes. Research Journal of Pharmacognosy 1, 13-19.

Venkatarayan SV. 1936 - The biology of Ganoderma lucidum on areca and coconut palms. Phytopathology 26, 153-175.

Vyas D, Seikh IA, Tiwari GK. 2016 - Role of Mushroom in Maintaining Mental Health with Special Reference to Anti-Convulsant Activity. The International Journal of Indian Psychology 4, 73-92.

Wachtel-Galor S, Choi SW, Benzie IFF. 2005 - Effect of Ganoderma lucidum on human DNA is dose dependent and mediated by hydrogen peroxide. Redox Report 10, 145-149.

Wachtel-Galor S, Yuen J, Buswell JA. 2011 - Ganoderma lucidum (Lingzhi or Reishi): A Medicinal Mushroom. In: Benzie IFF, Wachtel-Galor S. (eds.) Herbal Medicine: Biomolecular and Clinical Aspects. 2nd edition. Boca Raton (FL), CRC Press/Taylor \& Francis 2011 Chapter 9.

Wagner R, Mitchell DA, Lanzi Sassaki G, Lopes de Almeida Amazonas MA et al. 2003 - Current techniques for the cultivation of Ganoderma lucidum for the Production of biomass, ganoderic acid and polysaccharides. Food Technology and Biotechnology. 41, 371-382.

Wang H, Ng TB. 2006 - Ganodermin, an antifungal protein from fruiting bodies of the medicinal mushroom Ganoderma lucidum. Peptides 27, 27-30.

Wang XC, Xi RJ, Li Y, Wang DM et al. 2012 - The species identity of the widely cultivated Ganoderma, 'G. lucidum' (Ling-zhi), in China. PLoS ONE 7, 40857.

Wasser SP. 2005 - Reishi or Ling Zhi (Ganoderma lucidum). In: Coates PM, Blackman MR, Cragg GM, Levine M, Moss J, White JD. (eds) Encyclopedia of dietary supplements. Marcel Dekker, New York 603-622.

Wasser SP. 2011 - Current findings, future trends, and unsolved problems in studies of medicinal mushrooms. Applied Microbiology and Biotechnology 89, 1323-1332. doi: 10.1007/s00253010-3067-4.

Wasser SP, Weis AL. 1999 - General description of the most important medicinal higher Basidiomycetes mushrooms. International Journal of Medicinal Mushrooms 1, 351-370.

Welti S, Moreau PA, Decock C, Danel C et al. 2015 - Oxygenated lanostane-type triterpenes profiling in laccate Ganoderma chemotaxonomy. Mycological Progress 14(7), 45.

Wong KL, Chao HH, Chan P, Chang LP et al. 2004 - Antioxidant activity of Ganoderma lucidum in acute ethanol-induced heart toxicity. Phytotherapy Research 18(12), 1024-1026.

Wong CL, Bong JFC, Idris AS. 2012 - Ganoderma species associated with basal stem rot disease of oil palm. American Journal of Applied Sciences 9, 879-885. 
Wu DT, Deng Y, Chen LX, Zhao J et al. 2017 - Evaluation on quality consistency of Ganoderma lucidum dietary supplements collected in the United States. Scientific reports 7, 7792. doi: 10.1038/s41598-017-06336-3

Wu Y, Choi MH, Li J, Yang H et al. 2016 - Mushroom Cosmetics: The Present and Future. Cosmetics 3-22.

Xie YZ, Zhang Z, Li SZ, Li C. 2002 - Recent advances in the development and processing works of the Ling-zhi fungus. Journal of Microbiology 22, 43-45 (In Chinese).

Yan L. 2015 - Gynostemma pentaphyllum (Thunb.) Makino (Jiaogulan, Five leaf Gynostemma). In: Liu Y, Wang Z, Zhang J. (Eds) Dietary Chinese Herbs Chemistry: Pharmacology and Clinical Evidence. Springer, London 615-622. doi 10.1007/978-3-211-99448-1_70.

Yan YM, Ai J, Zhou LL, Chung AC et al. 2013 - Lingzhiols, unprecedented rotary door-shaped meroterpenoids as potent and selective inhibitors of p-Smad3 from Ganoderma lucidum. Organic Letters 15, 5488-5491.

Yan YM, Wang XL, Luo Q, Jiang LP et al. 2015 - Metabolites from the mushroom Ganoderma lingzhi as stimulators of neural stem cell proliferation. Phytochemistry 114, 155-162.

Yang LZ, Feng B. 2013 - what is the Chinese "Lingzhi"? - A taxonomic mini-review. Mycology, an International Journal on Fungal Biology 4, 1-4.

Ying JZ, Mao ZL, Ma QM, Zong LC et al. 1987 - Icons of medicinal fungi from China. Science Press, Beijing 1-579 (in Chinese).

Yu YN, Shen MZ. 2003 - The history of Lingzhi (Ganoderma spp.) cultivation. Mycosystema 22, 3-9 (in Chinese).

Yue GG, Fung KP, Leung PC, Lau CB. 2008 - Comparative studies on the immunomodulatory and antitumor activities of the different parts of fruiting body of Ganoderma lucidum and Ganoderma spores. Phytotherapy Research 22, 1282-1291.

Yuen WMJ, Gohel MDI. 2005 - Anti-cancer Effects of Ganoderma lucidum: A Review of Scientific Evidence. Nutrition and Cancer 53, 11-17.

Zhao S, Ye G, Fu G, Cheng JX et al. 2011 - Ganoderma lucidum exerts anti-tumor effects on ovarian cancer cells and enhances their sensitivity to cisplatin. International Journal of Oncology 38, 1319-1327.

Zhao Y. 2015 - Panax ginseng: Root, Rhizome, Tuber, and Bulb Materials. In: Liu Y, Wang Z, Zhang J. (Eds.) Dietary Chinese Herbs Chemistry: Pharmacology and Clinical Evidence. Springer, London 182-191.

Zhang HJ, Cao LS, Ye SQ. 2004 - Measures of log-cultivated Ganoderma lucidum for highyielding and quality. Journal of Agricultural Sciences 3, 136-138 (In Chinese).

Zhang J, Tang Q, Zhou C, Jia W et al. 2010 - GLIS, a bioactive proteoglycan fraction from Ganoderma lucidum, displays anti-tumour activity by increasing both humoral and cellular immune response. Life sciences 87, 628-637.

Zhang LH, Wang SX. 2010 - Study on the binding and packing cultivation technology of the $G$. lucidum's artificial alternative compost. Agriculture Technology Service 27, 516-517 (In Chinese).

Zhang W, Tao J, Yang X, Yang Z et al. 2014 - Antiviral effects of two Ganoderma lucidum triterpenoids against Enterovirus 71 infection. Biochemical and Biophysical Research Communications. doi:http://dx.doi.org/10.1016/j.bbrc. 2014.05.019.

Zhang XQ, Ip FC, Zhang DM, Chen LX et al. 2011 - Triterpenoids with neurotropic activity from Ganoderma lucidum. Natural Product research 25, 1607-1613.

Zhou LW, Cao Y, Wu SH, Vlasák J et al. 2015 - Global diversity of the Ganoderma lucidum complex (Ganodermataceae, Polyporales) inferred from morphology and multilocus phylogeny. Phytochemistry $114,7-15$.

Zhou SF, Gao YH. 2002 - The immunomodulating effects of Ganoderma lucidum (Curt. Fr.) P. Karst. (Lingzhi, Reishi mushroom (Aphyllophoromycetideae). International Journal of Medicinal Mushrooms 4, 1-11. 
Zhou XW, Su KQ, Zhang YM. 2011 - Applied modern biotechnology for cultivation of Ganoderma and development of their products. Applied Microbiology and Biotechnology 93, 941-963. doi: 10.1007/s00253-011-3780-7.

Zhou Y, Chen S, Ding R, Yao W et al. 2014 - Inflammatory Modulation Effect of Glycopeptide from Ganoderma capense (Lloyd) Teng. Mediators of Inflammation Article ID 6912858 pp. doi:http://dx.doi.org/10.1155/2014/691285.

Zhu K, Nie S, Li C, Xie M. 2013 - A newly identified polysaccharide from Ganoderma atrum attenuates hyperglycemia and hyperlipidemia. International journal of biological macromolecules 57, 142-150.

Zhu KX, Nie SP, Tan LH, Li C et al. 2016 - A Polysaccharide from Ganoderma atrum Improves Liver Function in Type 2 Diabetic Rats via Antioxidant Action and Short-Chain Fatty Acids Excretion. Journal of agricultural and food chemistry 64, 1938-44.

Zhu XL, Chen AF, Lin ZB. 2007 - Ganoderma lucidum polysaccharides enhance the function of immunological effector cells in immunosuppressed mice. Journal of Ethnopharmacology 111, $21-226$. 